\title{
ENTRE CONSTRUÇÕES E REPRESENTAÇÕES DO TRÁFICO DE MULHERES PARA PROSTITUIÇÃO, DA VULNERABILIDADE E DO CONSENTIMENTO: UM ESTUDO CRÍTICO SOBRE A APLICAÇÃO DA NORMA INCRIMINADORA PELO SISTEMA DE JUSTIÇA CRIMINAL
}

\author{
Paulo César Corrêa Borges ${ }^{1}$ \\ Luiz Henrique Garbellini Filho
}

\begin{abstract}
RESUMO
Este trabalho é oriundo de pesquisas financiadas pela FAPESP e pelo CNPq e teve como escopo principal refletir sobre a resposta jurisdicional dada à aplicação da norma penal incriminadora do tráfico sexual, sobretudo nos casos judicializados em que a mulher consentiu com seu tráfico num contexto de suposta vulnerabilidade. Essa aplicação envolveu profundas discussões em torno do consentimento como meio de dissolver a tipicidade material desse crime, pois o conceito de vulnerabilidade é altamente impreciso. Após o estudo do panorama penal de repressão ao tráfico sexual e sua intersecção com o Sistema Penal, foi analisado o parâmetro de reconhecimento da vulnerabilidade, com o suporte das categorias analíticas do capitalismo e de gênero. Por fim, com os recursos epistemológico da Criminologia Crítica, da Criminologia Crítica Feminista e da Análise do Discurso, foram questionadas as ações e os discursos do Sistema de Justiça Criminal como aspectos de construções e representações de simbolismos na (des)proteção dos direitos sexuais das mulheres traficadas para exploração sexual que consentiram com o fenômeno. A análise qualitativa de acórdãos publicados pelos Tribunais Regionais Federais (TRFs) permitiu revelar que a resposta jurisdicional mais reforça os padrões de gêneros do que rompem com as agências de controle sexual sobre a mulher.
\end{abstract}

Palavras-chave: Sistema de Justiça Criminal; tráfico de pessoas para exploração sexual; prostituição; vulnerabilidade; consentimento.

\section{INTRODUÇÃO}

O presente trabalho é fruto de resultados de pesquisas financiadas pela Fundação de Amparo à Pesquisa no Estado de São Paulo (FAPESP) e pelo Conselho Nacional de Desenvolvimento

\footnotetext{
${ }^{1}$ Pós-doutor pela Universidad de Sevilla (Espanha). Graduado, mestre e doutor pela Universidade Estadual Paulista "Julio de Mesquita Filho" (UNESP/Franca). É professor assistente-doutor de Direito Penal da UNESP no âmbito da graduação e da pós-graduação. Foi coordenador da PPGDIREITO - Programa de Pós-graduação em Direito da UNESP. É coordenador do Núcleo de Estudos da Tutela Penal e Educação em Direitos Humanos (NETPDH). É Promotor de Justiça do Ministério Público do Estado de São Paulo. Email: paulo.cc.borges@unesp.br.

2 Acadêmico em Direito pela Universidade Estadual Paulista "Júlio de Mesquita Filho" (UNESP/Franca). Atualmente, é bolsista FAPESP (processo 18/02101-2), inclusive com realização de estágio de pesquisa na Facultad de Derecho da Universidad de Sevilla (Espanha). Foi bolsista do CNPq. É membro do Núcleo de Estudo da Tutela Penal e Educação em Direitos Humanos (NETPDH) e do Grupo de Pesquisa Direito e Mudança Social (Demus). E-mail: luiz.henrique.garbellini@gmail.com.
} 
Tecnológico e Científico (CNPq) no âmbito das investigações empreitadas pelo orientando e pelo orientador na temática da (ir)relevância do consentimento para a caracterização do crime de tráfico sexual previsto pela legislação penal brasileira.

A pesquisa a ser apresentada nesse artigo foi construída com base nos dados já levantados em etapas prévias das investigações citadas, sendo, portanto, fruto da discussão e reflexão sobre os resultados obtidos nos meses subsequentes. A pesquisa original instrumentalizou os campos epistemológico da Antropologia, da Sociologia Jurídica, das Ciências Criminais, - sobretudo do Direito Penal e das Criminologias - e da Linguística para atingir os resultados finais a serem discutidos no artigo em questão. Abordagem transdisciplinar se mostrou necessária frente à complexidade multifatorial da temática da resposta jurisdicional ao tráfico sexual de mulheres, desde a seara sociológica, passando pela criminal, até o campo jurídico-linguístico.

Após o emprego do Direito Penal, com suporte de metodologia dialética, para compreender criticamente o trato legislativo criminal a esse fenômeno no Brasil, os dados confeccionados pela pesquisa original a respeito do recorte socioantropológico do tráfico sexual foram articulados sob égide do método qualitativo, com o estudo de literatura feminista e anticapitalista, além de emprego pesquisas de campo anteriormente produzidas por especialistas na área do tráfico de mulheres. Em seguida, os estudos originais se debruçaram no âmbito da Criminologia - sobretudo Crítica e Feminista - e da Linguística - principalmente da Análise do Discurso - para embasar o estudo empírico qualitativo dos acórdãos proferidos pelos Tribunais Regionais Federais (TRFs) que envolvam tráfico sexual de mulheres, consentimento e vulnerabilidade social, a serem debatidos no presente trabalho.

Então, como instrumento de compilação e de debates críticos sobre os dados obtidos durante o cronograma de pesquisa, o presente trabalho teve por objetivo refletir sobre as práticas e os discursos da resposta jurisdicional do Sistema de Justiça Criminal quanto à aplicação da norma penal incriminadora do tráfico sexual.

De início, pontua-se que as expansões do Neoliberalismo e da globalização capitalista são um dos instrumentos contemporâneos de produção de desigualdades e de opressões sociais, com repercussões diretas no fomento ao deslocamento de seres humanos em função de precárias conjunturas de acesso aos bens socioeconômicos e aos direitos humanos. Nesse contexto, o tráfico de pessoas assume uma importância fundamental nas relações de migração internacional em razão das assimetrias internas e externas dos países (RUBIO, 2015, p. 21), principalmente no que toca às mulheres como indivíduos migrantes que buscam emancipação social.

Não seria um equívoco metodológico, então, vincular o tráfico de pessoas ao fenômeno da feminização dos fluxos migratórios. Há o ingresso de mulheres oriundas de países subdesenvolvidos no mercado de trabalho informal e/ou ilegal de nações desenvolvidas, com intuito de propulsionar 
condições de subsistência para si ou para a família, refletindo dinâmicas de opressões sociais, notadamente de gênero, no que se relaciona ao "mercado do sexo", termo empregado por Adriana Psicitelli (2007) em sua pesquisa de campo sobre brasileiras na indústria do sexo na Espanha para denotar a amplitude dos serviços sexuais prestados no campo do tráfico sexual.

Nesse contexto se insere o tráfico de pessoas para exploração sexual como uma das principais modalidades do tráfico humano e como consequência da feminização da migração. Afinal, a vulnerabilidade de mulheres de regiões menos abastadas socioeconomicamente pode ser articulada como uma das pontes para o ingresso de mulheres na prostituição em outros países. Diante disso, porquanto há projeção do serviço sexual como produto consumível frente ao contexto de migração de mulheres, o arcabouço jurídico do Brasil concentrou esforços para coibir o tráfico de pessoas para exploração sexual.

Em 2004, houve a incorporação do Protocolo Adicional à Convenção das Nações Unidas contra o Crime Organizado Transnacional Relativo à Prevenção, Repressão e Punição do Tráfico de Pessoas, em Especial Mulheres e Crianças (Protocolo de Palermo), via Decreto no 5.017/2004 (BRASIL, 2004), bem como alterações na legislação penal de combate a essa modalidade de tráfico, como a Lei 13.344/2016 (BRASIL, 2016) que adicionou o artigo 149-A ao Código Penal, revogando o artigo 231 e 213-A do mesmo diploma legal.

Não obstante o fenômeno jurídico buscar o aprimoramento da tutela dos direitos humanos das mulheres traficadas, essa modificação no Código Penal brasileiro não se incumbiu de solucionar uma importante problemática de política criminal com reflexões na (des)garantia de direitos sexuais: a questão do consentimento válido da mulher traficada como meio de dissolver a tipicidade do delito, frente ao cenário de vulnerabilidade social.

Desse modo, considerando-se que, nos crimes contra liberdade sexual, o instituto do consentimento pode ser considerado a base de todo o sistema desses delitos (GRECO; RASSI, 2010, p. 76), a omissão da legislação quanto ao consentimento mulher traficada faz com que o Sistema de Justiça Criminal pavimente essa lacuna. Como consequência, há complexos debates que podem ser mobilizados na compreensão da problemática ação desse Sistema no que toca às dominações de gênero instrumentalizadas pelo fenômeno jurídico-penal.

Finda a exposição da problemática inicial, a pesquisa teve como escopo fundamental analisar criticamente os discursos e as práticas da resposta jurisdicional para a aplicabilidade da norma penal incriminadora do tráfico sexual. Para tanto, foi imprescindível trilhar investigações a respeito do estudo sobre a interconexão entre Justiça Criminal e panorama penal de combate ao tráfico de pessoas para exploração no Brasil para, posteriormente, analisar, com amparo da Sociologia Jurídica e das Teorias Feministas, a relação entre a vulnerabilidade e consentimento como parâmetro para a tutela penal dos direitos humanos das mulheres traficadas. Outrossim, para 
se atingir ao objetivo principal, a pesquisa também debruçou esforços no estudo sobre a Criminologia Crítica e Criminologia Crítica Feminista como elementos epistemológicos de compreensão da (des)proteção dos direitos sexuais das trabalhadoras do sexo traficadas.

Diante disso, a última etapa da investigação científica concentrou suas considerações a respeito do Sistema de Justiça Criminal a partir de um estudo documental de acórdãos. Além do amparo dos referenciais teórico-metodológicos citados, foi necessário também mobilizar campos epistemológicos da área da Linguística, sobretudo, da Análise Crítica do Discurso (ACD). Com o emprego do método de abordagem dialético e do método de procedimento empírico-analítico, analisaram-se qualitativamente 12 decisões judiciais prolatadas de 2012 a 2018 nos casos judicializados que envolvem tráfico sexual, vulnerabilidade e consentimento. Essa análise incidiu sobre acórdãos dos Tribunais Regionais Federais da $1^{\mathrm{a}}, 3^{\mathrm{a}}$ e $5^{\mathrm{a}}$ Região, fontes primárias para análise qualitativa das informações e das narrativas jurídico-argumentativas empregadas pelos desembargadores e desembargadoras.

\section{A LEGISLAÇÃO PENAL BRASILEIRA E JUSTIÇA CRIMINAL: O COMBATE AO TRÁFICO DE PESSOAS PARA EXPLORAÇÃO SEXUAL E A OMISSÃO QUANTO AO INSTITUTO DO CONSENTIMENTO}

As agências sociais de dominação de gênero postularam e ainda postulam a supremacia da figura masculina sobre a figura feminina em diversas as esferas da sociedade e das relações de poder vigentes. A naturalização da violência contra a mulher e a banalização da proteção aos seus direitos, principalmente sexuais, para além de um plano simbólico e social, projetaram-se no direito a partir de normas jurídicas androcêntricas e misóginas. A aplicação do fenômeno jurídico, sobretudo penal, por causas multifatoriais e complexas, demonstra, muitas vezes, uma ação criminal machista e patriarcal, com base em mecanismos criadores de diferenças de gêneros.

A mobilização do direito protagonizada pelo movimento feminista no Brasil, notadamente após a promulgação da Constituição Federal de 1988 e redemocratização do país, impactou substancialmente a alteração das normas penais que dificultavam a efetiva garantia dos direitos das mulheres. Antes do advento das teorias feministas críticas ao direito, vislumbrava-se um caráter essencialmente patriarcal no Código Penal brasileiro, afinal, a tutela penal era focada nos interesses androcêntricos e na moral social (MÉDICI, 2007, p. 365), sobrepondo-se a proteção aos "bons costumes" à liberdade e dignidade sexuais.

No que se relaciona ao tráfico sexual, uma das mais importantes alterações no ordenamento jurídico brasileiro foi a Lei 11.106/2005 (BRASIL, 2005), não obstante ainda persistir ausência quanto à referência ao instituto do consentimento no texto legal. A reforma abarcou a alteração da redação do artigo 231 e 231-A que outrora criminalizava, respectivamente, o tráfico internacional e interno para exploração sexual. Com isso, a expressão "tráfico de mulheres" presente na redação 
do dispositivo foi alterada para "tráfico de pessoas", ou seja, a vítima do crime poderia ser tanto homem quanto mulher, evidenciando um avanço feminista a respeito da igualdade de gêneros.

Antes da Lei 11.106/2005, o sujeito passivo era unicamente a mulher, havendo também compreensões doutrinárias de que a mulher somente era sujeito passivo indireto, pois o crime feria a moral pública, bem jurídico pertencente à sociedade. Ademais, houve revogação do crime de "rapto de mulher honesta" previsto pelo artigo 219, o que evidenciava que a aplicação do Direito Penal passava por um o crivo moral da aplicação fenômeno jurídico que tornava somente certas mulheres dignas de tutela estatal. Nesse sentido, não seria infirmado conceber que os processos de aplicabilidade da lei penal com base na moral social se aproximam dos pensamentos de Vera Regina Pereira de Andrade (2012, p. 143): o julgamento de um crime que envolve a sexualidade é uma arena na qual são julgados o comportamento da vítima, a sua vida pregressa, bem como a sua reputação.

Alguns anos após, a Lei 12.015/2009 (BRASIL, 2009), ainda sem menção ao instituto do consentimento, trouxe consigo a alteração do título ao qual pertencia o dispositivo que criminaliza o tráfico de pessoas para exploração sexual: "Dos crimes contra os costumes" para "Dos crimes contra a dignidade sexual", evidenciando que, ao menos em tese, o bem jurídico a ser tutelado pelo Direito Penal passaria a ser a dignidade e a autonomia sexual, deixando de ser a "honra e os bons costumes".

De acordo com o caput dos artigos 231 e 231-A do Código Penal, subentendia-se que a criminalização em questão era das condutas que envolviam o deslocamento de pessoas traficadas para exercício da prostituição, ou de "outra forma de exploração sexual”, como traz a redação do dispositivo penal, não apresentando diferenciação entre a prostituição como atividade laboral consentida - e a escravidão sexual como uma forma contemporânea de trabalho escravo - não consentida.

Explicita-se, pois, uma evidente limitação da liberdade sexual da mulher, afinal, de acordo com o tipo penal, mesmo que a mulher consentisse validamente com seu tráfico para o exercício da prostituição em outro país, a conduta migratória para exercício de um labor sexual em outro país era passível de persecução e punição pelo Sistema de Justiça Criminal.

Assim sendo, segundo Paulo César Corrêa Borges,

Trata-se de um sistema paternalista, moralista e puritano, que adota como classificação absoluta da prostituição como forma de exploração sexual, abrangendo a prostituição exercida como atividade laboral voluntária e, efetivamente, realizando uma inversão ideológica a pretexto de proteção de grupos vulneráveis de pessoas que se dedicam à prostituição em determinadas regiões do país, ou pretendam realizá-la no exterior. (BORGES, 2013, p. 33)

A repressão ao tráfico, então, não se centrava na manifestação da vontade das trabalhadoras do sexo; por conseguinte, não merecia relevância, sob as lentes de um olhar vitimológico, o desejo 
da mulher em exercer a profissão sexual em outro país. Diante disso, Kamala Kempadoo (2005, p. 78) já denunciava em seus trabalhos que o combate ao tráfico sexual, entendido como um problema de migração internacional do trabalho, vem ativando mecanismos de controle migratório. Revelase, na realidade, um intuito de política criminal de combate ao tráfico de pessoas para exploração sexual: evitar o deslocamento de indivíduos que exercessem um trabalho "indesejável" para a moral da sociedade, frente aos estigmas machistas e misóginos que as trabalhadoras do sexo sofrem.

No atual trato penal ao tráfico sexual, ainda persiste essa omissão quanto ao instituto do consentimento, levando os magistrados conceberem os parâmetros de entendimento da aplicabilidade da norma incriminadora por meio da interpretação que circunda seu foro íntimo de opiniões e ideologias. Não obstante o advento da Lei 13.344/2016 ter se caracterizado como uma importante reforma no combate ao tráfico de pessoas para exploração sexual, não houve destaque ao consentimento na redação dos artigos.

Essa lei buscou adequação ao Protocolo de Palermo, incorporado pela legislação brasileira pelo Decreto $n^{0} 5.017 / 2004$, mas não se incumbiu de romper integralmente com essas problemáticas de gênero que envolvem o tema. Com a reforma, os artigos 231 e 231-A foram revogados e acrescentado o artigo 149-A ao Código Penal, fundindo-se o tráfico internacional e nacional de pessoas para exploração sexual em um só dispositivo, que também conta com a criminalização do tráfico para formas contemporâneas de escravidão apresentadas pelo Protocolo de Palermo.

Art. 149-A - Agenciar, aliciar, recrutar, transportar, transferir, comprar, alojar ou acolher pessoa, mediante grave ameaça, violência, coação, fraude ou abuso.

Pena - reclusão, de 4 (quatro) a 8 (oito) anos, e multa. § 20 A pena é reduzida de um a dois terços se o agente for primário e não integrar organização criminosa.

I - remover-lhe órgãos, tecidos ou partes do corpo; II - submetê-la a trabalho em condições análogas à de escravo; III - submetê-la a qualquer tipo de servidão; IV - adoção ilegal; ou V - exploração sexual.

$\S 1$ o A pena é aumentada de um terço até a metade se: I - o crime for cometido por funcionário público no exercício de suas funções ou a pretexto de exercê-las;

II - o crime for cometido contra criança, adolescente ou pessoa idosa ou com deficiência;

III - o agente se prevalecer de relações de parentesco, domésticas, de coabitação, de hospitalidade, de dependência econômica, de autoridade ou de superioridade hierárquica inerente ao exercício de emprego, cargo ou função; ou

IV - a vítima do tráfico de pessoas for retirada do território nacional. (BRASIL, 2016)

De início, pontua-se que a legislação trouxe explicitamente uma guinada na política criminal em relação ao crime de tráfico de pessoas para exploração sexual, pois só criminalmente punida a conduta que visa a exploração sexual, diferenciando-a, em tese, da prostituição voluntária. Apesar de persistir omissão quanto ao instituto do consentimento, a partir de estratégia interpretativa, não seria uma incoerência afirmar que, como consequência prática do dispositivo, o consentimento 
válido da pessoa traficada retiraria a tipicidade do crime de tráfico de pessoas para exploração sexual, se não houvesse os requisitos para promover a conduta: mediante grave ameaça, violência, coação, fraude ou abuso.

Nesse caso, o indivíduo titular dos bens jurídicos liberdade e dignidade sexuais, em função da livre decisão consciente, cooperaria para a disposição desses bens jurídicos. Afinal, considerando-se que o consentimento sem vícios descaracteriza o desvalor da ação e do resultado (ROXIN, 1997, p. 517), tornaria um indiferente penal a conduta de tráfico de pessoas para exploração sexual.

Todavia, convém explicitar que as pesquisas de Heleieth Saffioti $(1987$, p. 14) a respeito de violência de gênero e direito trazem a confirmação de que as alterações legislativas não são, por si só, elementos de transformações das estruturas e das agências sociais de controle da sexualidade da mulher.

A modificação de leis, muitas vezes, vem acompanhadas pela necessidade de uma resposta jurisdicional quanto à interpretação da norma e a formação de um juízo interpretativo sobre o tráfico sexual está involucrado em causas multifatoriais que envolvem a moral e a cultura da sociedade brasileira. Ainda, as alterações legislativas anteriores sobre tráfico sexual foram observadas pelo Judiciário e seus sentidos foram valorados pela convicção dos magistrados, servindo de base de dados para pesquisas empíricas já empreendidas no campo do estudo de acórdãos a serem debatidas.

Assim como se procederá a análise de acórdãos coletados pela presente pesquisa, a perspectiva de moralismos e preconceitos em torno da legislação sobre o tráfico sexual e de sua aplicação foi estudada também por Ela Wiecko de Castilho (2008), corroborando a ideia de que alterações na lei penal não traduzem necessariamente mudanças positivas no trato à questão. A pesquisadora investigou a temática do tráfico de mulheres para prostituição em outro país, debruçando-se sobre a análise de 23 decisões judiciais proferidas entre 2004 e 2008, com o intuito de verificar se o Sistema de Justiça Criminal busca romper com a discriminação de gênero e com a revitimação.

Ela Wiecko identificou nas narrativas jurídicas que a prostituição viabilizada pelo tráfico geralmente não é entendida como um labor e nem mesmo demanda esforço, sendo exercida por mulheres em contexto de miséria e de degradação moral, sem capacidade para o consentimento. Juntamente, notou-se uma repressão penal ao tráfico sexual, como proposta dos magistrados para solucionar o fenômeno.

Esses resultados de pesquisa empírica já realizada no campo dialogam diretamente com a instrumentalização do Direito Penal como política de tentativa de impedir um labor considerado culturalmente imoral por diversas sociedades: a prostituição viabilizada pelo tráfico sexual de mulheres. Assim, durante o processo de aplicabilidade da norma penal visando a regulação 
migratória, transparecem-se as bases de estudo do trabalho em questão: as explícitas - e implícitas - concepções ideológicas e simbólicas dos magistrados durante as narrativas e argumentações jurídicas, como a ideia de "infantilização" da mulher denunciada por Castilho em sua investigação empírica.

Essa "infantilização" das mulheres pelo Sistema de Justiça Criminal acompanha a ideia de que as trabalhadoras do sexo traficadas não possuem capacidade, ou ao menos discernimento, para consentir validamente com seu tráfico para prostituição em outro país. Trata-se de uma visão que menospreza a liberdade e emancipação sexual das mulheres, vinculando-as a padrões comportamentais de submissão, e não de subversão de seu contexto social. Com isso, a atuação desse órgão do Sistema Penal, ao buscar suprir a lacuna legal do consentimento da pessoa traficada para o serviço sexual, oscila entre os polos de proteção e desproteção de seus direitos sexuais, enquadrando a figura da mulher prostituta na expressão que Ana Gabriela Mendes Braga (2013, p. 219) qualificou de "vítima-vilã".

Assim, a reforma suscitada pela Lei 13.344/2016, frente à ausência do instituto do consentimento no texto da lei, vem sendo levada ao crivo do Sistema de Justiça Criminal para consolidação do entendimento jurisprudencial a respeito da relevância do consentimento para a caracterização do crime de tráfico de pessoas para exploração sexual, notadamente em razão da expressão multisemântica "abuso" presente no artigo 149-A do Código Penal.

Diante das reflexões suscitadas a respeito da legislação em torno do tráfico de pessoas para a exploração sexual, a problemática a ser discutida pela pesquisa se centrou também na expressão "abuso" para macular o consentimento da trabalhadora do sexo, pois a jurisprudência vem pavimentando tal fosso ao atribuir-lhe as categorias de entendimento para o sentenciamento nos casos judicializados.

\section{A VULNERABILIDADE COMO PARÂMETRO PARA O VÍCIO DO CONSENTIMENTO NO CRIME DE TRÁFICO DE PESSOAS PARA EXPLORAÇÃO SEXUAL}

O Protocolo de Palermo é o documento internacional de maior importância na disciplina jurídica ao tráfico de pessoas, atuando na complementaridade com o direito doméstico brasileiro no combate às diversas formas de tráfico para escravidão contemporânea. $\mathrm{O}$ documento traz uma especial preocupação com o "abuso da vulnerabilidade" como meio de cooptar a suposta vítima para o exercício da exploração sexual em outro país, de modo a invalidar o consentimento da pessoa traficada. Ainda, o Protocolo, em seu artigo $9^{\circ}$, item 4, traz explícita referência aos elementos que contribuem para essa vulnerabilidade e facilitação para o tráfico de pessoas, como "pobreza, subdesenvolvimento e desigualdade de oportunidades que tornam as pessoas, especialmente as mulheres e as crianças, vulneráveis ao tráfico" (BRASIL, 2004). 
Não obstante a incorporação do Protocolo de Palermo no ordenamento jurídico brasileiro pelo Decreto $n^{0} 5.017 / 2004$, as discussões em torno da sua implementação não foram acompanhadas de uma atenção especial acerca do abuso da situação de vulnerabilidade como meio de conseguir o consentimento da pessoa a ser traficada (CASTILHO, 2013, P. 134). Afinal, o próprio artigo 149A do Código Penal traz uma expressão altamente imprecisa: "abuso", suscitando diversas interpretações a respeito das questões de gênero, do capitalismo e do eurocentrismo que podem contribuir, de uma forma ou de outra, para invalidar ou reafirmar a anuência da mulher para o seu tráfico.

Em suas pesquisas acerca do tráfico de pessoas para exploração sexual, Laura Lowenkron (2015, p. 228-229) buscou entender o trato jurídico contemporâneo à sexualidade e às sensibilidades sociais quanto a violência sexual. Defendeu que o consentimento e a vulnerabilidade são elementos chaves e conexos para a construção e desconstrução da ideia de vitimização. Suscitou também que a vulnerabilidade é categoria polissêmica que pode dissolver os valores simbólicos e jurídicos atrelados ao consentimento.

No mesmo sentido dispôs Adriana Piscitelli (2006, p. 21) em suas investigações sobre migrantes brasileiras na Espanha para exercício da prostituição, quando explorou a crucialidade da compreensão do termo altamente impreciso "abuso de vulnerabilidade" para aferir a questão do consentimento.

Não é possível dissociar a questão do consentimento ao debate sobre a vulnerabilidade social das mulheres traficadas. Isso porque as categorias de vulnerabilidades - e suas profundidades e complexidades - podem fornecer as bases e os parâmetros de compreensão da invalidez do consentimento e, assim, regular a incidência do direito como mecanismo de tutela de direitos humanos. Como consequência, o fenômeno jurídico aparece como elemento para proteção - ou desproteção - da mulher ingressa no tráfico sexual.

Frente a isso, há relevantes debates em torno dos elementos que determinam a vulnerabilidade das supostas vítimas, com repercussões nas políticas criminais contra essa forma de tráfico e na proteção criminal, já que a vulnerabilidade é parâmetro para tutela penal dos direitos humanos (BORGES, 2012, p. 84). Nesse panorama de polissemias da vulnerabilidade, o tráfico de pessoas para exploração sexual se enquadra num contexto de assimetrias sociais e de controle das agências de regulação social e estatal sobre o corpo da mulher dentro do processo de (des)construção de direitos humanos. Compreender, então, as manifestações da sociedade androcêntrica e capitalista é uma faceta fundamental da temática da vulnerabilidade, com o intuito de aferir os parâmetros sociais para a ação do fenômeno jurídico quanto ao consentimento.

Dentro de um plano simbólico e material, capitalismo e gênero devem ser instrumentalizados categorias analíticas por uma perspectiva feminista para entender as lógicas de 
dominação e de subversão que configuram a invalidez do consentimento da mulher supostamente vítima de tráfico de pessoas para exploração sexual. Trata-se de uma questão regulada por paradigmas morais que se reproduzem na forma de compreender o próprio direito e a efetivação das garantias sexuais das mulheres como instrumentos emancipadores ou dominadores no convívio social.

O mercado capitalista de produção é responsável pela formação de abismos sociais e, consequentemente, de produção de vulnerabilidades e opressões. Nessa dinâmica, Boaventura de Sousa Santos, Conceição Gomes e Madalena Duarte (2009, p. 72) aduzem que a globalização neoliberal é um dos instrumentos chaves de fomento ao tráfico de seres humanos, frente à dessocialização do capital que dificultou a seguridade dos direitos sociais e promoveu a vulnerabilidade social. Para os autores, uma das consequências disso é o surgimento da "indústria do sexo", na qual principalmente mulheres de países mais pobres de deslocam aos países mais ricos para prostituição, voluntária ou involuntariamente.

Não se pode deixar de destacar também que as bipolaridades entre concentração de riqueza e miséria designam fossos sociais na garantia de mínimas condições de sobrevivência. Por conseguinte, o tráfico de pessoas é um fenômeno resultante do mecanismo de funcionamento lucrativista do capitalismo que promove opressões estruturais e verticaliza as relações sociais (RUBIO, 2013, p. 259-260). Isso porque não se nega que há situações em que as degradantes condições sociais, educacionais, culturais e econômicas, às quais a pessoa traficada se insere, retiram do ser humano sua qualidade mais intrínseca: a capacidade de se tornar sujeito de sua própria história com instrumentos mínimos para sua manutenção no corpo social. Diante disso, configurase o tráfico sexual no qual o indivíduo não possui autonomia para reafirmar sua identidade e negociar suas condições de trabalho sexual no livre-mercado.

A ausência de meios de sobrevivência pode ser empregada como elemento fomentador de abusos de redes internacionais de tráficos para cooptar vítimas e outorgá-las a atividade sexual sem o seu consentimento válido. Dependendo da dinâmica do tráfico sexual, a dignidade da pessoa humana vem sendo aviltada em razão da ausência do mínimo existencial para a manutenção da vida, o que leva redes de tráfico a instrumentalizarem mulheres para auferirem lucros sobre a extrema miséria socioeconômica, invalidando sua real capacidade reflexiva e intelectual em torno de seu desejo de laborar sexualmente em outro país.

De outro lado, a realidade do tráfico sexual é múltipla e sua compreensão não dever ser limitada a pré-noções e moralismos. Compreender essa multiplicidade traduz vislumbrar situações em que o tráfico sexual se constitui em um meio da pessoa traficada se desenvolver economicamente e efetivar sua participação na sociedade capitalista, reafirmando sua cidadania social e política. Então, faz-se necessário repensar as noções sobre o consentimento no tráfico 
sexual para concebê-lo também como instrumento de emancipação e subversão social com o intuito de evitar incongruências metodológicas.

Para tanto, é válido afirmar que somente a dimensão analítica do capitalismo, por si só, não seria efetiva para a análise do consentimento para o tráfico sexual no contexto da vulnerabilidade. As investigações científicas de Rosa Cobo (2011, p. 67) quanto à temática da prostituição no cenário do capitalismo e do machismo tratam de explicitar que o sistema capitalista de produção e o patriarcado pactuam uma política sexual para que os direitos das mulheres sejam mais precários, com maior potencialidade para violações.

As formas de opressão que circundam a questão da vulnerabilidade para o tráfico sexual não devem ser compreendidas como variáveis independentes. As categorias de classe, sexualidade e etnia trazem consigo uma intersecção de dominações, de modo que não são categorias autônomas, pois concorrem para a edificação das violações de direitos humanos, operando uma sobre a outra (FLORES, 2005). Dessa forma, para além do capitalismo, o emprego das relações de gênero como categoria analítica para compreender a questão da vulnerabilidade é intrínseco ao estudo sobre o tráfico sexual, vulnerabilidade e consentimento.

O debate segue em torno da dominação estrutural do patriarcado e do machismo, dentro de uma visão de gênero. Para Joan Scott (1995, p. 86), gênero se divide em dois subconjuntos interrelacionados: ao mesmo momento em que se configura num elemento constitutivo das relações sociais de diferenças entre os sexos, também se constitui numa forma primária de traduzir as relações de poder. Corresponde-se a um processo de naturalização de uma discriminação exclusivamente histórica e sociocultural, frente a dinâmicas de violência ou de emancipação sobre o corpo da mulher. Com isso, o universo semântico do gênero reflete diretamente nas discussões quanto a (in)validade do consentimento da mulher quanto ao seu tráfico sexual.

A temática encontra fonte teórica já nas primeiras pesquisas feministas sobre o tráfico para exploração sexual, a partir do sistema cunhado por Gayle Rubin (1993, p. 23) de sexo/gênero. Para a autora, esse sistema possibilita trabalhar gênero como categoria analítica a fim de estudar como a sexualidade humana é produto para a economia. Conforme pontua, com base em sistemas culturais machistas e capitalistas, o corpo da mulher é instrumentalizado e controlado por outrem para a exploração sexual com o intuito de lucrar.

Ainda, para Emma Goldman (1997), a mulher é socialmente educada para se transformar em uma mercadoria sexual, que terá um valor dependendo de sua posição na escala moral e na vida pública. Para ela, a prostituição, através de contratos informais, advém da coisificação da sexualidade da mulher. Por conseguinte, a atividade da prostituição é socialmente criminalizada pelo fato da venda do corpo feminino se dar fora dos paradigmas institucionais e simbólicos dominados pela figura masculina e destinado à figura feminina 
Há um terreno em disputa no que se refere aos entendimentos feministas sobre a questão da prostituição e, consequentemente, do tráfico sexual. Como extensão, os debates dos diversos feminismos têm suas essências na questão dos parâmetros e das compreensões sobre a vulnerabilidade de gênero. $\mathrm{Na}$ realidade, há inúmeras correntes de pensamento dentro do movimento feminista a respeito das temáticas da prostituição, mas as correntes que encontram maior embasamento e destaque na literatura científica correspondem, sobretudo, ao feminismo radical e o feminismo liberal.

Tratam-se de polos divergentes sobre o entendimento a respeito do trabalho sexual, na medida em que representantes do feminismo radical como Catharine Mackinnon, Andrea Dworkin e Kathleen Barry postulam que a prostituição é fundamentalmente caracterizada pela dominação masculina, sendo a atividade sexual inerentemente contrária à emancipação de gênero. Em via contrária, representantes do feminismo liberal como Kamala Kempadoo e Jô Doezema, organizadoras da coletânea Global Sex Workers, afirmam que a prostituição pode ser uma atividade de subversão, pois, a mulher, ao impor seu papel sexual e sua autodeterminação, rompe com a moral por um ato de afronta ao patriarcado-capitalista que lhe impõe a dominação sexual.

As reflexões de Mackinnon (1995, p. 242) encontram o sentido de a prostituição ser um campo impossível para subversão e libertação feminina. Por sua vez, Dworkin (1989) dialoga com a questão ao propor que mesmo que a mulher creia consentir com uma relação heterossexual, como a prostituição, será submetida à dominação de um sistema patriarcal e machista. Ainda, para Barry (1995), a prostituição deveria ser alvo de criminalização. Essas autoras visualizam, sobretudo, a prostituição como uma ditadura do falo na medida em que o sexo é uma bandeira da dominação masculina sobre as mulheres, tratadas de forma inexoravelmente vulneráveis.

Em via distinta, Kempadoo (2005, p. 62) negou enfaticamente a vinculação obrigatória entre prostituição e violência contra o gênero feminino. Enfatizou que, na realidade, as precárias condições de vida e de trabalho, bem como os pânicos e violências que circundam o mercado num setor informal ou subterrâneo são aspectos que infringem garantias fundamentais das mulheres. No mesmo sentido, Doezema (1999, p. 33) sugere a compreensão em torno da dicotomia "escolha" e "força", isto é, entre prostituição voluntária e forçada, como meio de efetivamente identificar violação de direitos humanos e dominação das mulheres. Essas autoras aduzem, principalmente, que o trabalho sexual pode surgir como espaço de empoderamento e libertação da corporificação de gênero.

A corrente de pensamento instrumentalizada pelo feminismo liberal se articula como principal referencial teórico adotado pela presente pesquisa, não obstante os esforços epistemológicos do feminismo radical possuírem também sua relevância e seu mérito científico. Isso porque adotar uma perspectiva unilateral quanto ao tema da vulnerabilidade da mulher no 
contexto do tráfico para as relações sexuais comerciais, se ao menos não traduz um equívoco metodológico, abarca uma visão simplista sobre as relações sociais que envolvem o tráfico transnacional, certo que a realidade do mercado sexual é amplamente diversificada.

Ainda, não se deve cometer incoerência de afirmar que, num sistema social de fortes disparidades sociais e econômicas como o latino-americano, o tráfico sexual e a prostituição não ocuparão, ao menos, uma das principais atividades na agenda de trabalho de muitas mulheres sendo boa parte delas em situação de pobreza, considerando-se a multiplicidade do mercado sexual. Então, adotar uma visão realista - e, por vezes, pragmática - sobre o tráfico sexual significa compreender a dinâmica das atividades sexuais transnacionais e promover propostas concretas para lidar social e juridicamente com esse fenômeno.

Em consonância, Dolores Juliano (2005, p. 95) versa no campo reflexivo do tráfico sexual ao aduzir que o trabalho sexual também deve ser compreendido como uma atividade voluntária. $\mathrm{Na}$ realidade, o deslocamento transnacional de mulheres com finalidade de exercício sexual não se enquadra necessariamente na prostituição forçada, afinal, as mulheres podem ser agentes ativos das dinâmicas do mercado do sexo quem envolvem bordéis, casas de massagens, turismo sexual, acompanhante de luxo, prostituição de rua e outras formas de labores sexuais viabilizadas pelo tráfico, dentro da dinâmica da "indústria do sexo". Para tanto, não se deve atribuir à prostituição adulta uma noção infanto-juvenil e passiva.

Além disso, pesquisas de campos já realizadas quanto à temática do tráfico sexual para exploração sexual atestam a multiplicidade da questão, corroborando a importância de se adotar o feminismo liberal como corrente mais adequada para compreender o fenômeno. Nas pesquisas empíricas empreitadas por Kamala Kempadoo $(2005$, p. 63) a respeito do tráfico de mulheres para prostituição, dados empíricos sobre a realidade dessa modalidade de tráfico surge como um rompimento de pânicos morais, pois expõem que a servidão por dívidas e o trabalho sexual contratado se fazem mais presentes no mercado sexual do que a escravidão propriamente dita.

Revela-se também que o trabalho sexual contratado traduz uma liberdade sexual no livre mercado da prostituição. As pesquisas de Adriana Piscitelli (2006, p. 21), a partir de entrevistas a mulheres traficadas na Espanha, aduzem uma evidente frequência na autonomia das mulheres quanto ao seu tráfico sexual, não apresentando autoconsciência de serem vítimas de uma exploração. Concluiu que ínfima parte das entrevistadas apontam para o vínculo de seu tráfíco com coação, engano, violência, controle, ou restrição da liberdade, sendo que algumas mulheres mencionaram enfaticamente: "vim porque quis". Piscitelli ainda interpretou que, na realidade, a própria consciência da vulnerabilidade dessas mulheres traficadas serve de motor para o deslocamento transnacional com escopo de oferecer serviços sexuais e buscar progressões socioeconômicas em suas vidas. 
Assim, se a vulnerabilidade outrora é entendida como fator inerente à mulher traficada pelo feminismo radical, outrora é enquadrada como possível mecanismo de superação das dominações de gênero pelo feminismo liberal, a representação desse conceito e dos elementos que a circundam se faz imprescindível. Para Bjarne Melkevik (2018, p. 647-648), a vulnerabilidade de um sujeito de direito deve ser compreendida em sua relação com a autonomia pessoal. Aduz o autor que o processo de se tornar autônomo, isto é, de desenvolvimento de competência cognitiva, está vinculado a uma perspectiva bicéfala: as circunstâncias da sociabilidade e a personalidade do indivíduo, no sentido de que a autonomia deve ser analisada de acordo com as suas relatividades e subjetividades pelo próprio sujeito em questão. Como consequência, a vulnerabilidade é manifestada pela recusa da autonomia e adesão à heteronomia - isto é, força desenvolvida pelo outro a fim de se submeter a ela.

Diante disso, tratar a vulnerabilidade socioeconômica e de gênero como paradigma absoluto não condiz com os devidos parâmetros para invalidade do consentimento para tráfico sexual. A prostituição voluntária está articulada diretamente com o contexto cultural, social, econômico e pessoal no qual se insere. Desse modo, atribuir às mulheres uma posição estritamente de submissão no contexto do mercado sexual é sinônimo de relegá-las à infantilização e ao menosprezo de sua autodeterminação sexual, negando, inclusive, a própria pluralidade da "indústria do sexo" quanto ao tráfico transnacional.

É certo que o labor sexual possibilitado pelo tráfico também traz consigo ações de negociação comercial, resistência e subversão da figura feminina quanto à venda de sua sexualidade, o que impossibilita tratá-las como sujeitos passivos e sem projetos próprios de vida. Assim, é necessário reconhecer a capacidade das mulheres traficadas no que toca à concordância e discordância com suas escalas, turnos e modos de prostituição em outra nação. Por isso, discursos que homogeneízam as realidades do tráfico, muitas vezes, vitimizam a mulher traficada, pois ao enquadrá-la na figura inerente de vítima, dificulta-se o rompimento de um padrão de sexualidade preestabelecido por uma moral androcêntrica, perpetuando a regulação social, bem como a manutenção das corporificações de gênero.

O enquadramento da mulher traficada como estritamente vulnerável reflete também na negação da ideia de consentimento válido para o tráfico sexual. Se o espaço de tráfico para prostituição suprime integralmente o empoderamento da mulher e sua liberdade corporal, o consentimento não traduziria efetivamente a vontade de consentir, pois este seria induzido pela dominação capitalista-machista fundada na ideia genérica de subordinação macrossociológica. Trata-se, na verdade, de um discurso paternalista de tutela ao corpo feminino e que não deve prosperar como perspectiva generalizadora sobre essa forma de tráfico humano. 
Por consequência, analisar os cenários de subversão ou de submissão no tráfico sexual impacta no reconhecimento de parâmetros para a compreensão da vulnerabilidade, evitando categorizar e generalizar a dinâmica do tráfico sexual para impedir "camuflagens sociológicas", termo cunhado por Boaventura de Sousa Santos, Conceição Gomes e Madalena Duarte (2009, p. 88) ao refletirem sobre os equívocos metodológicos que podem induzir a ideia de que o tráfico sexual se traduz a uma visão unilateral, eivada de pânicos morais. Corresponde-se a uma linha tênue, mas que deve ser estabelecida para a efetiva tutela sexual das mulheres que se inserem nesse multifacetado mercado sexual. Diante disso, compreender que o fenômeno jurídico-penal deve ter sua ação regulada pelas características subjetivas e específicas de cada caso em particular é imperativo.

As pesquisas de McClintock (1993, p. 06) dialogam com a questão na medida em que aponta que a violação de direitos fundamentais e à dignidade da prostituta se dá quando se remove o poder de escolha da prostituta: se, como, quando e onde laborar sexualmente. Então, aproveitando-se da ausência de capacidade da suposta vítima do tráfico sexual em negociar e estabelecer a sua lógica sexual, a consequência fática é invalidar o consentimento pelo abuso da vulnerabilidade de gênero.

Então, postular que a tutela penal dos direitos humanos da mulher traficada não deve ser regulada por limites traduz uma visão andrógina da aplicação do instrumento jurídico. É importante não adotar o entendimento de que o abuso de vulnerabilidade ocorre somente pelo fato de a suposta vítima pertencer ao gênero feminino e às classes sociais menos favorecidas financeiramente. Pelo contrário, o abuso da vulnerabilidade deve ser interpretado na medida em que a mulher traficada não pode ser ou não é suficientemente emancipada cognitiva e socialmente para expressar, articular e negociar suas demandas e desejos quanto a atividade sexual que exercerá no mercado sexual transnacional, tendo, então, seu consentimento prejudicado. Isto é, a vulnerabilidade ocorre porquanto a mulher a ser traficada não está apta para negociar seu posto de trabalho e sua dinâmica sexual, sendo assim submissa às relações de poder econômico e patriarcal.

A compreensão dessa complexa dinâmica em torno do tráfico sexual, vulnerabilidade e consentimento é fundamental para se estabelecer os paradigmas e modelos de ativação da tutela penal das garantias previstas constitucionalmente. Não se trata de um debate que deve estar vinculado somente à seara sociológica e antropológica, mas que também deve ser objeto, com o suporte, sobretudo, das Teorias Críticas do Direito, de uma investigação crítica sobre a própria maneira do Sistema de Justiça Criminal abordar a temática.

\section{4. À LUZ DA CRIMINOLOGIA CRÍTICA E DA CRIMINOLOGIA CRÍTICA FEMINISTA: O SISTEMA PENAL COMO (DES)GARANTIA DOS DIREITOS SEXUAIS DAS TRABALHADORAS DO SEXO TRAFICADAS}


Boaventura de Sousa Santos (2005, p. 45) aduz que as sociedades representam uma imagem transmitida nos espelhos que refletem identificações dominantes em certo contexto histórico. Um desses espelhos, conforme o autor, corresponde ao campo jurídico-procedimental da normatividade do direito que reflete a moral na qual uma sociedade está imersa. Não seria um erro metodológico, então, propor que a atuação e articulação do fenômeno jurídico na questão do tráfico sexual reproduz estruturas do patriarcalismo, sedimentando dominações sobre a corporificação feminina pelo Sistema de Justiça Criminal.

A Constituição Federal de 1988 estabeleceu pela primeira vez a necessidade de reconhecer como valor nuclear a igualdade entre os gêneros num olhar democrático sobre as relações sociais. Não obstante a inclusão no ordenamento jurídico nacional de normas constitucionais de isonomia de gênero, além de normas internacionais e legislações específicas de combate ao tráfico sexual, coibir as assimetrias e opressões históricas ainda se mostra como ação obstaculizada perante a dificuldade dos instrumentos jurídicos em garantir a previsão de igualdade material entre homem e mulher.

Nesse âmbito se enquadram as Teorias Crítica do Direito com o emprego de uma visão dialética das relações sociais e do fenômeno jurídico, evitando a representação restrita do formalismo jurídico universalista. Afinal, a instrumentalização da dialética como princípio metodológico trata de superar as oposições e integrar visões conflitantes para se atingir uma síntese (COSTA; COELHO, 2017, p. 26).

Os pensamentos críticos e emancipatórios da Criminologia Crítica e Criminologia Crítica Feminista vão se assentar na denúncia ao sistema penal como falha na promessa de garantia a direitos fundamentais. Esses recursos epistemológicos descortinam uma notória contradição no Sistema Penal entre a igualdade formal dos indivíduos e desigualdade substancial entre os sujeitos de direito. Entretanto, esse paradigma nem sempre prosperou no pensamento criminológico ocidental.

Os estudos sobre a prostituição pela Criminologia perpassam o século XIX até a atualidade. Uma das primeiras representações da mulher prostituta remete a Cesare Lombroso e Guglielmo Ferrero, expoentes da Criminologia Positivista, quando publicaram La Donna Delinquente de 1893, na qual os autores italianos (LOMBROSO, FERRERO; 2004) subdividiram as mulheres em normais, criminosas e prostitutas, todas consideradas inferiores aos homens, pois pensam e sentem menos. A representação da imagem mulher prostituta encontrou suas causas na construção dos gêneros, certo que esses criminólogos atribuíam-lhe a condição de degenerada socialmente, pois tinha como características a sexualidade exacerbada, presença de qualidades masculinas, falta de afeto maternal, etc. Para os autores, a figura da mulher prostituta representava a classe perigosa e a degradação moral. 
Esse paradigma seguiu como modelo criminológico por considerável lapso temporal. Se ao menos não guiou a compreensão social e jurídica sobre a prostituição por diversas décadas, ao menos repercutiu certos efeitos residuais na maneira com que as mulheres prostitutas eram tratadas ao longo dos anos subsequentes à publicação da obra italiana. O advento da Criminologia Crítica no século XX não revisitou totalmente esse paradigma criminológico sobre as prostitutas, porque não incorporou integralmente uma visão feminista em relação à crítica ao direito, apesar de ter um caráter fundamental para se compreender as dinâmicas seletivas, restritas e preconceituosas da aplicação do fenômeno jurídico nos espaços de sociabilidade,

A omissão da Criminologia Crítica quanto a essa questão veio a ser suplantada, notadamente a partir da década de 1980, pelo emprego de um paradigma de gênero para denúncia ao perfil androcêntrico da ciência jurídica moderna: a Criminologia Crítica Feminista, desenvolvida epistemologicamente na perspectiva da Criminologia Crítica. Isso ocorreu porque diversas criminólogas trataram de defender que a gênese da opressão sobre as mulheres não deve ser delimitada ao capitalismo, pois o patriarcado é anterior ao fenômeno do capital, atuando de modos distintos no controle social. Por conseguinte, a Criminologia Feminista revisitou os padrões criminológicos tradicionais de compreensão sobre o entrelace entre gênero e o fenômeno criminal, remodelando-os e atribuindo-lhes novas categorias de sentido.

É nessa dinâmica, então, que se encontra a necessidade de uma "reconstrução social do gênero", expressão cunhada por Alessandro Baratta (1999, p. 22) para superar as dicotomias artificiais das relações simbólicas culturalmente estabelecidas nas esferas funcionais, isto é, na ciência e no direito. Baratta, assim como diversos expoentes da criminologia, aduziu que é necessário um rompimento epistemológico com a Criminologia Crítica, passando a compreender o Sistema de Justiça Criminal também sob as lentes de uma visão feminista. Por conseguinte, a Criminologia Crítica Feminista superou as limitações metodológicas da Criminologia Crítica quanto ao estudo de opressão estrutural das mulheres pelo Sistema de Justiça, certo que passou investigar a aplicação do direito com o imprescindível suporte de um recorte de gênero, num objeto de estudo ampliado.

Dentro do campo epistemológico da Criminologia Crítica Feminista, Carol Smart (1994, p. 170-171) entende que o direito é "sexuado", pois coloca as mulheres em posição de desvantagem em relação aos homens, inclusive quando se não reconhecem os danos que as mulheres sofrem quando dessa posição de submissão, a exemplo das leis que tratam do universo da prostituição. Adiciona que o direito é produzido para os homens, na medida em que atende às bandeiras da dominação do patriarcado.

Ainda, Smart (2000, p. 40-41) revela a análise do direito como processo de produção de identidades de gêneros fixos, o que relega a análise da aplicação da dogmática-jurídico penal a 
sujeitos que já possuem um gênero. Assim, o direito é um instrumento que constrói posturas subjetivas dotadas de gêneros, isto é, corresponde a uma estratégia criadora de distinções sexuais, dentro da noção de que "o direito possui gênero" e de que o "direito é masculino", como instrumentalizado pela autora. A produção de normas jurídicas e a sua destinação, então, são orientadas para o benefício do gênero masculino.

Em uma perspectiva feminista, a adoção do gênero como categoria de análise para compreender a ação do Sistema Penal descortina e desmistifica os estigmas e preconceitos sexistas quanto à compreensão da conduta delitiva e do controle social sobre as mulheres. Assim sendo, em com base nessa premissa, permite-se articular debates sobre o trato do Sistema de Justiça Criminal às mulheres traficadas para exploração sexual.

No debate da matéria, a junção entre os campos epistemológicos do feminismo e da Criminologia tem apresentado críticas contundentes ao trato que o Sistema de Justiça Criminal tem oferecido às mulheres traficadas. Os estudos criminológicos sobre o tráfico sexual têm denunciado um caráter androcêntrico da aplicação do fenômeno jurídico. Na maioria das vezes, a atuação desse sistema tem mostrado uma ideia de menosprezo à capacidade cognitiva e intelectual das mulheres, indicando um estereótipo machista: as mulheres traficadas vêm sendo tratadas como seres de menor potencialidade reflexiva, pois estão ligadas ao mundo da prostituição, invariavelmente ligado à degradação moral sob o crivo interpretativo dos membros da Justiça Criminal.

Os resultados de pesquisas empíricas já realizadas na seara criminológica vem mostrando que o Sistema Penal tem lidado de maneira equivocada com o tráfico sexual. Essa ação do Sistema de Justiça Criminal se opõe às considerações e conclusões de pesquisa que Ela Castilho (2013, p. 143) já vinha traçando sobre o tema: a vulnerabilidade é um instrumento que encaminha medidas para proteção a certos grupos sociais, mas com o zelo de, sob um discurso de proteção, não se reforce discriminações de gênero, cerceando-se a liberdade das mulheres.

Torna-se evidente que a articulação da dogmática jurídico-penal no caso do tráfico para prostituição demonstra que o processo de criminalização e de percepção social da criminalidade está involucrada à noção de vulnerabilidade absoluta das mulheres traficadas para o exercício sexual. Diante disso, sob a escusa de articular uma tutela penal aos direitos humanos das mulheres, na realidade, a (des)proteção estatal promove a sua violação com o intuito de proibir a saída do Brasil de trabalhadoras do sexo para a indústria do sexo transoceânica.

Os estudos criminológicos feministas e críticos na temática de tráfico sexual, consentimento e vulnerabilidade denunciam que o direito insurge como expressão - e também criação - das qualidades e valores que se encontram na base da dicotomia na construção social de gênero, correspondendo a um processo de edificação de identidades fixas de gênero. Isso porque as agências de criminalização secundária mostram-se como meio de infantilizar as mulheres traficadas pelo 
tráfico, atribuindo-lhes uma postura de submissão, na qual o cenário de subversão não se mostra potente. Com isso, o Sistema de Justiça Criminal contribui para a produção material e simbólica das desigualdades de gênero, articulando uma retroalimentação do machismo infiltrado no seio social e jurídico.

A retroalimentação dos mecanismos de controle social entre sociedade e sistema jurídicopenal não passou despercebida pelos expoentes da Criminologia. Para tal, Alessandro Baratta (1999, p. 42) pontuou que a dependência recíproca entre sistema penal e a dinâmica da sociabilidade devese ao fato desses dois elementos possuírem dimensão material e simbólica. Para o autor, os elementos simbólicos da estrutura social, como os papéis de gênero, condicionam elementos materiais do sistema penal, e vice-versa.

Essa perspectiva crítica se materializa na maneira do Sistema de Justiça Criminal compreender a relação entre divisão social do trabalho e padrões de sexualidade. Sabe-se que a noção de prostituição, no plano simbólico-cultural da sociedade, é vinculada à figura feminina fragilizada, por vezes ligada à degradação moral e à “demonização". Assim sendo, frente ao papel de vítima invariavelmente rotulado à vulnerável prostituta traficada, a atuação do Sistema Penal trata de espelhar a realidade social e o plano simbólico do machismo e concorrer para a reprodução da noção - social e jurídica - de vítima.

Na mesma lógica, Gerlinda Smaus (1998) dispõe que a aplicação do Direito Penal atua como elemento de regulação específica das dinâmicas de trabalho em uma sociedade, com consequências na esfera da moral do trabalho e da ordem social. Conforme pontua a autora, o sistema penal trata de sancionar as desobediências à moral do labor de forma a garantir a desenvoltura das relações de produção conforme a previsão da moral. Assim, o Sistema de Justiça Criminal induz a disciplina e regulação dos grupos localizados na margem do mercado oficial de trabalho.

Com base no metadiscurso de Smaus, não seria um equívoco afirmar que a ação moralista do Sistema Penal abarca o domínio patriarcal do direito na esfera privada vinculada às negociações sobre o tráfico sexual, nas quais as demandas da figura feminina muitas vezes é um elemento-chave. A criminalização do tráfico sexual serve para representar simbolicamente o papel conferido à mulher na esfera moral da sociedade: submissão e vulnerabilidade. Dessa maneira, quando a mulher subverte a lógica de dominação, ofende a construção de gênero perante a Justiça Criminal e perante a sociedade, ativando mecanismos do Sistema Penal para a sua repressão.

Então, o controle penal ao tráfico sexual como meio de coibir o deslocamento de mulheres para a venda de sua sexualidade é sinônimo de corroborar o papel moralizador do Estado e do direito na (des)tutela dos direitos de prostitutas traficadas. A regulação da prostituição por meio do Sistema 
Penal, atribuindo às mulheres traficadas o panorama de extrema vulnerabilidade, insurge mecanismos de manutenção da própria sociedade que repudia a prostituição como atividade laboral.

Essas considerações sobre tráfico sexual, vulnerabilidade e consentimento não estão dissociadas dos resultados das pesquisas de Vera Regina Pereira de Andrade (1999, p. 113) a respeito de Justiça Criminal e gênero. A pesquisadora traz que que o Sistema Penal torna a mulher vítima de uma violência institucional plurifacetada, ao reproduzir a violência estrutural das relações sociais capitalistas e patriarcais, com a consequência de reprodução de estereótipos, como no campo da moral sexual.

Assim, paralelamente no tráfico sexual, o sistema penal trata de retificar as pré-noções e pânicos morais ao vincular as supostas vítimas ao campo de fraude, ilusão, violência e coerção no exercício da prostituição. O discurso e a ideologia do Sistema Penal em torno da defesa da sociedade, da família e dos "bons valores", na realidade, são mecanismos de violentar a liberdade sexual das mulheres traficadas, o que contribui para uma construção - e reprodução - simbólica dos pânicos morais e dos pré-conceitos circundados no tráfico sexual. Como resultado, a ação do fenômeno criminal interrompe a atividade laboral da suposta vítima, promovendo um entrelace entre os elementos de poder estatal e social sobre a mulher.

Essas demandas judiciais relacionadas ao tráfico sexual, vulnerabilidade e consentimento têm sido levadas à segunda instância do Judiciário, para uma resposta jurisdicional sobre os parâmetros de atuação do Direito Penal. Sabe-se que o artigo 155 do Código de Processo Penal pressupõe a livre convicção do julgador como instrumento de solução dos litígios judiciais. Entretanto, essa construção aparentemente livre deve ser compreendida no campo de ideologias, morais e preceitos culturais que envolvem o foro íntimo e pessoal dos magistrados. Com essa reflexão inicial, a pesquisa concentrou esforços no estudo documental de acórdãos.

\section{O CONSENTIMENTO E O SISTEMA DE JUSTIÇA CRIMINAL: SUBVERSÃO OU SUJEIÇÃO? UM ESTUDO EMPÍRICO SOBRE A APLICAÇÃO DA NORMA PENAL INCRIMINADORA DO TRÁFICO SEXUAL (2012-2018)}

A temática perpassa a perspectiva de Pierre Bourdieu (1989) quanto à disputa no campo jurídico entre a conservação e subversão da estrutura de poder que o direito estabelece. De acordo com o autor, há, de um lado, a tentativa de manutenção do formalismo da lei e do descolamento da norma jurídica em relação ao mundo material, concebendo-se o fenômeno jurídico como um instrumento a serviço das classes dominantes. Há, por outro lado, a concepção de busca pela emancipação e por estratégias de inovação no modelamento do direito em relação às conquistas sociais.

Notadamente após o advento do fenômeno do ativismo judicial e a consolidação do Judiciário como terreno para instrumentalização de mudanças da sociedade pela dialética jurídica, 
este Poder tem ampliado sua atuação sobre as interpretações das normas jurídicas e resolução de problemáticas no que toca as demandas sociais das mulheres. Com isso, o Judiciário tem sido palco de lutas que envolvem a tentativa de reconhecimento e de conquista de direitos perante o combate à desigualdade de gênero. Não obstante, essa mobilização do direito deve vir relacionada ao seguinte debate: nesse palco de lutas, os direitos das mulheres têm assumido papel de personagem principal ou coadjuvante?

Nessa seara se encontrou a pertinência de investigação a respeito da emancipação ou dominação de gênero no que tange as ações e os discursos jurisprudenciais sobre a (ir)relevância do consentimento da mulher para o seu tráfico sexual. Investigar a articulação da lógica jurídica e de seu arcabouço ideológico a respeito do tema significa colocar sob custódia o Sistema de Justiça Criminal e observar o emprego do Direito Penal como meio de (des)garantia dos direitos sexuais das mulheres traficadas. Trata-se de analisar se as mulheres traficadas são (des)protegidas sob o prisma da subversão ou da conservação do mecanismo machista e patriarcal que involucra esse braço do Sistema Penal. O reconhecimento do consentimento válido como meio de dissolver a tipicidade penal seria, então, um reconhecimento da emancipação sexual das mulheres, bem como combate às assimetrias outorgadas pelo patriarcado.

Diante disso, o delineamento da investigação foi guiado por algumas inquietações a serem respondidas no decorrer do presente trabalho: Qual foi a compreensão dos desembargadores e desembargadoras a respeito da relação entre vulnerabilidade, prostituição e consentimento na dinâmica do tráfico sexual? Esses julgadores analisaram o caso de tráfico sexual consentido à luz da perspectiva de gênero com o intuito de não ratificarem a discriminação de gênero contra as mulheres traficadas? Os discursos e práticas no Sistema de Justiça Criminal revelaram que direito também é masculino no que toca o trato penal às mulheres que consentiram com seu tráfico?

De acordo com Paulo Eduardo Alves da Silva (2017, p. 285), os litígios judiciais representam as dinâmicas de um complexo jogo institucional de poder entre os atores públicos e privados. O Judiciário tem sob sua guarda uma parte da regulação das relações sociais, políticas e econômicas. Diante disso, as pesquisas sobre as decisões de processos judiciais permitem compreender a maneira como as questões formais são empregadas pelos decisores na busca de solução de conflitos.

O estudo de que trata o trabalho em questão foi vinculado a uma análise documental de acórdãos. Esses documentos públicos foram articulados como fontes primárias de informações no estudo empírico, certo que essa fonte é aquela que permite ao pesquisador se aproximar ao máximo do objeto a ser pesquisado (REGINATO, 2017, p. 198).

Quanto ao recorte institucional e espacial adotado, o corpus de estudo corresponde aos acórdãos proferidos pelo Tribunal Regional Federal da $1^{\mathrm{a}}$, da $3^{\mathrm{a}}$ e da $5^{\mathrm{a}}$ Região, fruto da pertinência 
temática e de sua relevância decisória. Por ora, esses TRFs são os únicos no Brasil que já decidiram sobre essa matéria após o advento da Lei 13.344/2016. Ainda, esses órgãos colegiados são as estruturas nas quais se insere um dos clímaces da ação legal e se consolida entendimentos, o que possibilitará a visão judicial geral sobre a aplicação da nova lei e sobre os eventuais remodelamentos advindos.

Para a busca dos acórdãos, por meio da pesquisa exploratória, empregaram-se os endereços eletrônicos do Portal de Jurisprudência Unificada do Conselho da Justiça Federal, bem como os sites dos TRFs citados para buscar o inteiro teor dos acórdãos. Desse modo, a coleta dos dados e confecção do material de análise foram viabilizadas pela busca feita por meio das palavras-chaves, contando com sinônimos: "tráfico de pessoas para exploração sexual" E "consentimento", ou “tráfico de pessoas" E "exploração sexual" E "consentimento", a fim de se atingir o recorte temático proposto. Outrossim, para formar a amostragem de informações, o recorte temporal conferido à pesquisa exploratória contempla os anos de 2012-2018. O banco de análise correspondeu a 12 acórdãos resolvendo o mérito de apelações criminais propostas pelos acusados e/ou pelo Ministério Público Federal, cujas origens advêm dos estados de São Paulo, Goiás, Mato Grosso, Mato Grosso do Sul, Bahia, Rio Grande do Norte e Acre.

O método qualitativo é o mais adequado para exprimir informações melhor detalhadas sobre os fenômenos e ajudar na edificação de novas categorias e novos conceitos (IGREJA, 2017, p. 16). Diante disso, para edificar as considerações científicas acerca das inquietações suscitadas, foi imprescindível uma análise qualitativa do corpus, pois o estudo se dirigiu à análise da postura opinativa dos desembargadores e das desembargadoras acerca da questão do consentimento. Com a análise qualitativa desses documentos judiciais, buscou-se, desse modo, entender o cenário em que foram confeccionados, os atores e os seus discursos que compõem as relações jurídicas, o conteúdo qualitativo das informações e narrativas expressadas.

A análise qualitativa dos acórdãos coletados demonstrou que os casos judicializados apresentam relativa variação quanto à dinâmica judicializada do tráfico para a exploração sexual. As referências aos autos instrumentalizadas pelos julgadores permitiram o entendimento de que as demandas judiciais levadas à segunda instância do Judiciário federal se relacionam às condenações em casos em que (i) houve efetivamente o emprego da fraude como meio de obter o consentimento das mulheres traficadas para exploração sexual, (ii) casos em que o tráfico para prostituição foi consentido sem vícios, (iii) casos em que o tráfico de pessoas consentido viabilizou serviços de dançarinas em boates, e ainda (iv) casos em que a prática do tráfico consentido para prostituição foi flagrada no aeroporto, obstaculizando o trajeto transnacional.

Não obstante o estudo em questão ter vislumbrado uma considerável gama de situações fáticas para se estabelecer juízos de valores sobre a atuação do Sistema de Justiça Criminal, da 
pequena amostra de material coletado não é possível apresentar resultados absolutos e incontestes sobre a temática, devendo as considerações e conclusões científicas serem interpretadas como sugestivas, com o intuito de se evitar equívocos metodológicos.

É nesse âmbito que residiu o norte da investigação: o vínculo dialético presente entre as premissas de gênero corroboradas pelo ordenamento constitucional pós-1988 que orientam o fenômeno jurídico brasileiro, e as normas e entendimentos de "gênero" que engendram as práticas e os discursos dos operadores do Sistema de Justiça Criminal. Trata-se de questão que supera a dimensão jurídico-procedimental das narrativas processuais, isto é, as táticas e técnicas jurídicas para resolução do mérito da apelação criminal. Num olhar transdisciplinar, o estudo perpassou também pela esfera discursivo-linguística das estratégias argumentativas empreitadas pelos julgadores durante o corpo textual dos acórdãos coletados. A análise incidiu, sobretudo, nas visões (ou cegueiras) de gênero que sustentam as decisões, dualidade mobilizada por Silvia Pimentel (2009, p. 27-30) em suas investigações sobre Lei Maria da Penha, gênero e direitos humanos.

O suporte teórico correspondeu ao campo criminológico e sociológico já delineado pela pesquisa original: Criminologia Crítica, a Criminologia Crítica Feminista e a teoria feminista de “Terceiro Mundo". Diante disso, buscou-se, com o método de abordagem dialético, compreender a relação entre o direito e os constructos sociais através das narrativas processuais, certo que esse método permeou a identificação de conflitos e, sobretudo, das contradições presentes na temática do consentimento da mulher traficada para prostituição.

Além disso, frente à proposição de análise do discurso, o trabalho se propôs também a empregar a teoria da Análise do Discurso Crítica (ADC) de Norman Fairclogh e os referenciais teórico-metodológicos, sobretudo, de Luis Alberto Warat e Leonel Severo Rocha, de Ruth Amossy e de Michel Pêcheux, considerando-se que o os acórdãos espelham uma dinâmica discursiva particular da comunidade em se insere o Poder Judiciário, denotando identidades sociais e valores construídos ao longo do texto jurídico.

Finalizada a apresentação do delineamento metodológico e teórico da pesquisa empírica, cabe ressaltar que Luis Alberto Warat e Leonel Severo Rocha em suas pesquisas sobre a relação entre Direito e Linguagem advogam que toda expressão traz consigo uma quantidade considerável de implicações não explícitas. Como pontuam os autores, a mensagem a ser transmitida não se finda na significação das bases dos termos linguísticos empregados. O processo de significação das construções frasais não é restrito à forma textual, pois também concorre com a materialidade ideológico-política da sociedade e do contexto comunicacional em que foi emitida a palavra. Nessa dinâmica surge o conceito de estereótipo, consistente em um termo linguístico que, com força conotativa e persuasiva, busca adesões valorativas e opiniões a partir da significação recebida de forma acrítica pelo leitor. A respeito dispõem os pesquisadores que 
As funções ideológicas cumpridas pelos estereótipos devem-se, principalmente, ao fato de que por seu intermédio são vinculadas certas afirmações ao sistema de crenças dominante. Nossa experiência cotidiana baseia-se em um conjunto de generalizações não rigorosas, que podem ser chamadas opiniões generalizadas. Os homens atuam e reagem comandados por essas crenças culturalmente institucionalizadas. O mecanismo linguístico mais apto para se obter esta institucionalização são os estereótipos, que, na maioria dos casos, forçam os receptores das mensagens a evocarem e aceitarem opiniões generalizadas (WARAT; ROCHA, 1995, p. 73)

A formação desses estereótipos foi comum nos acórdãos coletados, a partir da formação de uma versão fictícia da realidade social que envolve o consentimento para o tráfico de pessoas para exploração sexual. Por conseguinte, o processo de estereotipação forneceu as bases discursivas do senso comum dos julgadores. Esses estereótipos codificaram as dinâmicas de dominação produzidas e reproduzidas no material discursivo dos acórdãos.

Diante disso, da leitura dos acórdãos, surgiram com relativa recorrência algumas ideias estereotipadas, como a inclinação opinativa de que a vulnerabilidade econômica é elemento inerente ao tráfico de mulheres para exploração sexual, corroborando a concepção recorrente de vínculo de degradação econômica com a prostituição viabilizada pelo tráfico.

[Argumenta o desembargador que] é inegável que o tráfico internacional de mulheres no Brasil representa uma triste página de nossa história, agravada, no mais das vezes, pela situação de pobreza e vulnerabilidade que se encontram parcela significativa da população nordestina.” (BRASIL, 2017a). (grifo nosso)

Por sua vez, em outro julgamento de apelação criminal, a desembargadora avaliou a condição para a criação da situação de vulnerabilidade ao tráfico de pessoas: "Todas as mulheres se encontravam em clara situação de vulnerabilidade no Brasil, sendo oriundas de camadas pobres da população" (BRASIL, 2013a). No mesmo acórdão, agravou as circunstâncias do crime, considerando-se que o réu "utilizou de uma situação de vulnerabilidade econômica e social com vistas à prática do delito". De outra banda, em outra decisão, o desembargador estabeleceu um vínculo intrínseco entre o tráfico para prostituição e a condição socioeconômica das supostas vítimas ao dizer que o acusado aproveitava "da péssima situação financeira das aliciadas, o que as levava a exercer tal ofício" (BRASIL, 2012a). Ainda, num outro acórdão, houve a construção do tráfico sexual como um pânico moral, inexistindo a visão do tráfico como meio de emancipação social, pois "o requisito central do tráfico é a presença do engano, da coerção, da dívida e do propósito de exploração" (BRASIL, 2013b).

Esses dados coletados convergiram com outras pesquisas já construídas no campo do tráfico sexual, revelando que o Sistema Penal não tem avançado no trato ao crime em questão. Com emprego de uma leitura sob as lentes do feminismo e da criminologia para criticar o Sistema de Justiça Criminal, Anamaria Venson (2017, p. 581) se debruçou na análise do trato do Sistema Penal às mulheres traficadas para exploração sexual no mercado transnacional, ao analisar 12 processoscrime referentes ao período de 1995-2012. Como resultado, constatou-se que os agentes do sistema 
penal têm uma noção de imutabilidade da vulnerabilidade dessas mulheres, tomando como regra geral e sem devida verificação. A prostituição, então, não é compreendida como instrumento de trabalho emancipado, e sim como um universo de abuso e de crime. As mulheres são, por conseguinte, invariavelmente vinculadas ao engano e à posição de vulneráveis.

Nota-se que, sob um discurso de enlace intrínseco entre tráfico sexual e condição de vulnerabilidade imutável das mulheres traficadas, esteve, na realidade, a construção de uma ficção da realidade como instrumento argumentativo para mobilizar a condenação. Sob uma visão pejorativa a respeito dessa forma de tráfico humano, foi recorrente a análise superficial da condição social, econômica, intelectual e política das supostas vítimas para atribuição da situação de vulnerabilidade, que usualmente foi tratada de forma presumida na narrativa processual, sem elementos notórios que corroborassem esse panorama de fragilidade social. Diante disso, nos acórdãos analisados, bastou que a mulher traficada integrasse a posição de vítima de uma "triste página na nossa história" no litígio judicial para que se depreenda juridicamente a sua condição de intensa marginalização social.

Trata-se de uma construção jurídica quanto ao entendimento da vulnerabilidade no âmbito dos acórdãos, que foi reproduzida corriqueiramente nos casos analisados. A vulnerabilidade vem sendo compreendida como elemento inevitável às mulheres traficadas, e não como uma categoria transversal e múltipla que possui várias escalas. Nas decisões analisadas, a instrumentalização da vulnerabilidade apareceu como causa de uma consequência fática: não é possível conceber a prostituição viabilizada pelo tráfico como fenômeno descolado de uma realidade de pobreza e de baixa instrução das supostas vítimas, afinal, como disposto na narrativa processual, as "péssimas condições financeiras" levam as mulheres a integrarem o tráfico sexual.

Esteve implícito, na realidade, um apagamento da visibilidade às supostas vítimas ao caso concreto, as quais ocupam uma "posição periférica" nos litígios judiciais, termo empregado nas investigações de Ana Sofia Schmidt de Oliveira (1999, p. 129) sobre Direito Penal e vítima. Então, as protagonistas do enredo do tráfico de pessoas foram, sobremaneira, invisibilizadas no discurso processual.

Além disso, a linguista Ruth Amossy (2006, p. 121) dialoga com o debate apresentado na medida em que explora o estereótipo na análise do discurso como representação de uma imagem coletiva simplificada confeccionada frequentemente como uma crença, isto é, um pré-conceito, o que determina atitudes e comportamentos. Sendo assim, o estereótipo da vulnerabilidade teve como incumbência (re)produzir os pânicos morais, as generalizações e pré-noções a respeito do tráfico de pessoas para exploração sexual. Esses elementos estereotipados foram frequentemente instrumentalizados institucionalmente no âmbito dos acórdãos para corroborar as condenações. 
Nesse cenário, a reprodução dos estereótipos nas narrativas encontradas propulsionou a vitimização secundária, isto é, a sobrevitimização das mulheres traficadas para prostituição. $\mathrm{O}$ fenômeno jurídico-penal, ao generalizar concepções sociais a respeito do tráfico sexual, ativa o aparato repressivo-controlador da jurisdição criminal. Isso porque a aplicabilidade da norma repressiva a essa modalidade de tráfico apareceu comumente condicionada à criação de uma vulnerabilidade absoluta às vítimas, utilizadas na narrativa processual de forma pragmática e utilitária no processo penal, conforme já denunciado por Ela Castilho (2008, p. 119) em suas análises de 23 decisões judiciais proferidas entre 2004 e 2008 sobre tráfico de mulheres para exploração sexual e Sistema de Justiça Criminal.

Ademais, o consentimento da mulher traficada também perpassou pelo crivo interpretativo do Sistema de Justiça Criminal como aspecto igualmente prejudicado pela vulnerabilidade. Nos casos anteriormente referidos, foi marcante a visão de que o consentimento da mulher é irrelevante para a (des)caracterização do crime de tráfico de pessoas para exploração.

[Argumenta a desembargadora que] a presença do consentimento prévio das mesmas antes da viagem não é causa suficiente para excluir a responsabilidade dos exploradores, pois ainda que tenham consciência das atividades que serão exercidas, as mulheres não têm idéia das condições em que a exercerão e, menos ainda, da divida que em geral contraem antes de chegar ao destino (...) A vontade de cada uma era mitigada pela necessidade e por causa dessa necessidade aceitaram ter seu corpo objeto de exploração sexual. O intuito da lei e do Protocolo Internacional foi proteger aqueles que não têm como optar pela proteção. A vulnerabilidade das pessoas traficadas pode ser social, econômica ou educacional. Em regra, a vulnerabilidade social é o que induz as vítimas a consentirem com uma das formas de exploração acima enumeradas, porquanto, estas se atraem pela possibilidade de uma vida melhor e abrem mão de sua liberdade em nome daquele objetivo. (BRASIL, 2013a) (grifo nosso)

Na mesma dinâmica de interpretação, outro desembargador no julgamento da apelação criminal (BRASIL, 2012b) relatou que o consentimento da mulher traficada não é responsável por excluir a culpabilidade do traficante e nem limitar direito da mulher traficada à proteção oficial. Novamente, a narrativa textual demandou processos de estereotipação para ratificar o entendimento jurídico e justificar a condenação. Sob o discurso de tutela estatal acerca dos direitos das mulheres traficadas, esteve subjacente um processo de infantilização da mulher e limitação da capacidade da suposta vítima em participar de seu tráfico sexual como agente livre e emancipado. Para tanto, fezse presente, em grande parte dos acórdãos, a mobilização de trechos de outros julgados e de doutrinadores para corroborar o entendimento, o que conota uma reprodução de estereótipos e senso comuns no Sistema de Justiça Criminal.

Esse processo de reprodução institucional das imagens e sentidos juridicamente construídos perpassou também pela análise interpretativa de Ana Lúcia Pastore Schritzmeyer (2004, p. 125) que estudou os "retratos padronizados e padronizadores" no Sistema de Justiça. Para a pesquisadora, no tocante à jurisprudência, os estereótipos na redação das decisões judiciais são propulsionados, na 
medida em que se revestem de "clichês" a serem aplicados em novos casos, daí a necessidade de analisar tais retratos.

Entretanto, a análise dos dados coletados vislumbrou um relativo rompimento desse retrato padronizado quanto ao consentimento em dois acórdãos coletados no banco de dados. $\mathrm{O}$ desembargador que julgou as mesmas apelações criminais instrumentalizou a lei 13.344/2016 para aferir que o consentimento válido desconfigura a tipicidade da conduta, pois o artigo 149-A do Código Penal prevê a violência, a grave ameaça, a fraude, a coação e o abuso como circunstâncias elementares do tipo penal.

A contrario sensu, se o consentimento é válido, ou seja, se ele foi deduzido sem grave ameaça, violência, coação, fraude ou abuso, não - ao menos na hipótese de exploração sexual, de que se cuida nos autos - não se configura o crime. No caso dos autos, basta o exame da denúncia para se verificar que não há nenhuma referência a algum tipo de grave ameaça, violência ou fraude, bastando para se concluir pela abolitio criminis. (BRASIL, 2017b) (grifo deles)

Pela análise, percebeu-se que o reconhecimento do consentimento válido como relevante para incidência da norma incriminadora só ocorreu com o advento da nova lei, o que denota um apego ao plano formal da lei pelos julgadores. Nas decisões coletadas, não houve resposta jurisdicional do consentimento como causa supralegal de exclusão da ilicitude, que poderia ter sido instrumentalizado em vários acórdãos nos quais restou evidente que não houve efetivo vício do consentimento das mulheres traficadas.

Não obstante o desembargador ter adotado uma postura vinculada à noção de emancipação feminina, certas construções frasais evidenciaram a recorrente infantilização das mulheres traficadas nas narrativas processuais. $\mathrm{O}$ mecanismo de infantilização foi corroborado pelas construções frasais empregadas no material discursivo dos acórdãos, considerando-se que, para Carol Smart (1976, p. 143) o papel tradicional da mulher é corroborado pelas instituições penais, como a passividade e docilidade.

Usualmente as referências às mulheres traficadas no corpo textual foram embasadas em termos do universo semântico infanto-juvenil, como a expressão "garotas", mesmo já atingido a maioridade. A ideia foi explicitada nos seguintes trechos: “(...) sendo que as garotas que estavam na agência de turismo prestaram depoimento (...)” (BRASIL, 2017b); “(...) teriam recepcionado e acolhido inúmeras garotas vindas de Natal/RN, promovendo o traslado, via terrestre, com destino à cidade do Porto, em Portugal, com a finalidade de se dedicarem às atividades de dança, exploração sexual (...)" (BRASIL, 2017a); "As garotas viajavam para a Espanha ciente de que o valor, aproximadamente cinco mil reais, despendido pelas acusadas com aquisição de passaporte (...)" (BRASIL, 2012c). Ainda, outro desembargador traçou o perfil das pessoas traficadas como sonhadoras e idealizadoras, sem efetiva noção da realidade, corroborando o campo de sentido da infantilidade e da fantasia: 
[Argumenta o desembargador que] É fato comum o "castelo de areia" que as pessoas com menor poder aquisitivo constroem nas suas imaginações quando se trata de viver no exterior. Imaginam enriquecer com pouco trabalho e, já tendo ouvido sobre várias pessoas que foram e se deram bem, fantasiam que é só chegar lá e pronto: trabalharão pouco e ganharão muito. (...) O que geralmente ocorre e o presente caso não é exceção - é que as vítimas, depois de muito fantasiarem, percebem que no exterior a vida também é real, com todas as agruras e vicissitudes daqui, e são dominadas por enorme sentimento de fracasso e frustração (BRASIL, 2014) (grifo nosso)

A análise do emprego da linguagem relacionada ao campo da infantilidade deve vir acompanhada das reflexões construídas por Norman Fairclough (2003), expoente da Análise Crítica do Discurso. O autor concentrou esforços na identificação e análise dos significados da linguagem quanto à capacidade dos textos de representar e construir as ações e os atores sociais. Segundo o linguista, a partir da análise do discurso, é possível retirar do texto três significados que agem associada e concomitantemente: o significado normal - o texto como instrumento de interlocução com os eventos sociais; o significado representacional - o texto como feição dos aspectos da sociedade; o significado identificacional - o texto como edificador de identidades.

A frequência do uso dos termos no universo de redução da capacidade cognitiva das mulheres no contexto dos acórdãos elencados denota, sobretudo, um significado representacional e identificacional do texto instrumentalizado pelos julgadores. Afinal, em consonância com as pesquisas de Alessandro Baratta já delineadas no artigo, o sistema penal tem como função (re)produzir estruturas sociais. Diante disso, é representacional na medida em que espelha uma visão social e moral a respeito das mulheres traficadas: submissas, pobres, vulneráveis, sem capacidade de consentir autonomamente com seu tráfico para prostituição e, por fim, impossibilitadas de prever as condições de trabalho que serão submetidas. Também admite um contorno identificacional, pois se constroem e se identificam atores sociais na narrativa judicial: o Estado paternalista e assistencialista, o traficante perverso e a vítima frágil, consolidando imagens e sentidos padronizados no Sistema de Justiça Criminal quanto a dinâmica do tráfico sexual.

Por consequência, é intrínseca a relação representacional e identificacional da linguagem com o processo de representação e de edificação do gênero versado por Teresa de Laurentis. Mobilizando-se a "tecnologia de gênero" como meio analítico, Laurentis (1994, p. 212) dita que "a construção do gênero é tanto o produto quanto o processo de sua representação", isto é, a construção e a representação do gênero é produto de um e processo do outro. Trata-se de interpretar o elucidado pela autora no âmbito da retroalimentação da construção do gênero, na medida em que ser representado ou representar-se como figura feminina alicerça e espelha atributos sociais, como o valor e o status desvalorizados da mulher na hierarquia social.

Essa perspectiva foi manufaturada e confeccionada nos acórdãos estudados na medida em que a representação - e construção - de gênero se vinculou à imagem de fraqueza social. $\mathrm{O}$ 
desembargador delineou a fragilidade das mulheres frente aos aliciadores que a levaram para a prostituição em outro continente: "Essas mulheres aliciadas tornam-se, pelas dificuldades econômicas e sociais que enfrentam, alvo fácil de organizadas redes criminosas de aliciamento de pessoas, para prostituição na Europa" (BRASIL, 2017a). Outro desembargador configurou a relação entre vítima-traficante no campo de sentido da escravização: "Endividadas e com os passaportes apreendidos pelos traficantes, não conseguem escapar desse infortúnio, prisioneiras de redes internacionais de prostituição" (BRASIL, 2014). Em outro acórdão, uma desembargadora, aduzindo que as mulheres traficadas não se veem como exploradas, prolatou a necessidade de o Estado atuar como figura de proteção às mulheres traficadas: "torna ainda mais imprescindível $a$ atuação do Estado na prevenção e repressão ao tráfico e assistência às mesmas" (BRASIL, 2013a).

Os linguistas Fairclough e De Melo (2012, p. 309-310) também destinaram estudos nos processos de representação por meio da linguagem, isto é, uma construção das práticas sociais por meio da significação dos textos. Conforme defendem os autores, há uma intrínseca relação entre a condição social de um grupo e as representações produzidas por eles, dependendo da posição e do status que ocupam no âmbito social. Desse modo, os desempenhos produzidos pelos atores sociais quanto à produção das representações derivam, sobretudo, da sua classe, sexo, nacionalidade, etnia ou culturas.

Em sentido semelhante dispõe Michel Pêcheux (1995, p. 159-162) ao aduzir que, no contexto da análise discursiva, o sujeito emissor do discurso deve ser compreendido no seu campo político-ideológico. Trata-se de vincular o emissor com a produção institucional das mensagens, com as dinâmicas de poder que antecipam as ações de enunciação do discurso, bem como as concepções ideológicas e política que o norteiam.

Diante disso, depreendeu-se dos acórdãos selecionados a ideia de que os julgadores, personificando a figura do Estado, transmitiram os constructos sociais e visões a respeito da vulnerabilidade, do consentimento e do tráfico de pessoas para prostituição. Configuraram-se como atores sociais que representam o Poder Público e transmitem valores sociais e juízos de opinião eivados de pré-conceitos e moralismos, afinal, as instâncias oficiais do direito, como as agências de criminalização secundária, atrelam-se aos mecanismos e às estruturas de relações de poder entre grupos sociais. Por conseguinte, também foram responsáveis por criarem os atores sociais estereotipados na dinâmica do tráfico de pessoas para prostituição.

Outro aspecto especialmente relevante compreendido a partir do estudo qualitativo dos acórdãos foi o juízo de valor negativo dos julgadores sobre a prostituição advinda pelo tráfico. Trouxe a desembargadora que

[Aduz a desembargadora que] mesmo que se aceite a versão de que não havia qualquer contato entre clientes e "funcionárias" (o que se faz apenas a título de argumentação, ante a farta prova dos autos), não se pode questionar que foram 
arregimentadas com o único propósito de servirem de objeto de satisfação sexual (mesmo que platônica). (BRASIL, 2013a) (grifo nosso)

Geralmente, fez-se presente a ideia de que o serviço sexual não constitui efetivamente em um trabalho, visto que diversas vezes houve o emprego de aspas quando se referiu à condição de prestadora de uma atividade sexual, o que reafirmou a visão de negação da instrumentalização do corpo da mulher para a atividade mercantil, inclusive quando se destina à "satisfação sexual, (mesmo que platônica)". Na mesma decisão, a julgadora, ao avaliar o motivo para o tráfico sexual, aduziu que é reprovável, “pois 'lucro' fácil seria o que impulsionava a conduta”, o que revelou de forma subjacente que o financiamento do tráfico, isto é, o dinheiro oriundo da atividade sexual das mulheres traficadas, é facilmente adquirido.

Ainda, conotando um apelo ao Direito Penal como instrumento de política migratória para o tráfico sexual, outro desembargador afirmou que um dos problemas para o combate ao tráfico sexual é a disparidade legislativa entre países de destino e fim, porquanto "exploração da prostituição está tipificada no Código Penal, na Espanha, por exemplo, a exploração sexual é relativamente liberada." (BRASIL, 2014).

Dentro do processo de significação dos termos textuais, os vocábulos empregados nas decisões coletadas versaram no mesmo sentido de rejeição à prostituição viabilizada pelo tráfico. Em diversos acórdãos, a referência à prostituição se deu por meio da expressão "meretrício em prostíbulo", palavras com teor socialmente negativo. Frente a isso, como consequência da visão judicial a respeito da temática, não ficou evidente, para os julgadores, a ideia de que as mulheres traficadas seriam trabalhadoras ou profissionais do sexo.

Trata-se, em verdade, de semelhante dinâmica de atuação do Sistema de Justiça Criminal nas investigações de Vera Andrade (1996, p. 83) sobre gênero e agências de criminalização secundária. Esse sistema se responsabiliza por reproduzir as estruturas, as instituições, os simbolismos e os mecanismos de controle social de gênero. Se no âmbito social não é permitido à mulher inverter os papéis sociais de vulnerabilidade e de fragilidade que lhes é imposto a partir da prática da prostituição como atividade de emancipação socioeconômica e de gênero, esse sustentáculo do Sistema Penal reproduzirá e construirá juridicamente essa visão simbólica de dominação pelo patriarcado.

Além disso, em certos trechos das narrativas processuais, houve referência à vítima e a sua família como contribuidoras para o tráfico sexual. Ocorreu uma culpabilização da mulher traficada, acusada de não corroborar com a instrução processual na medida em que em certo acórdão houve negação do exercício da prostituição por parte das supostas vítimas na instrução processual: "embora tenham as brasileiras - de forma compreensivel, dada sua situação pessoal-negado o exercício de prostituição em estrito senso, clara está a exploração com apelo sexual do corpo de cada uma delas visando o lucro" (BRASIL, 2013a). Em outro acórdão, o núcleo familiar surgiu 
também como elemento contributivo para o tráfico, reafirmando a ideia de degradação moral e familiar que involucra o imaginário cultural - e também da comunidade jurídica - sobre essa forma de tráfico humano: "Tenha-se que o Brasil é o país de origem das pessoas traficadas e, por isso mesmo, tem dificuldades em combater o tráfico, que conta, muitas vezes, com a colaboração da própria família da vítima, por mais incrível que se possa imaginar” (BRASIL, 2013b).

Embora haja a pretensão de que o direito e a linguagem por ele instrumentalizada sejam neutros e sem crivos morais, os processos de significação operados pelo emprego do léxico e de construções frasais estereotipadas representam uma simbologia social e jurídica, na medida em que as ações e omissões nos textos são ideológicos. Para tanto, o estudo do dito e do não dito circunda as reflexões de Amossy (2005, p. 126) quando aduz que o estereótipo permite identificar a maneira de raciocínio pertencente a um grupo, bem como as visões do setor no qual ele se insere.

Então, entre o não dito nos acórdãos analisados esteve narrativa de gênero que deve ser inerente a essa forma de tráfico humano. Os paradigmas jurídico-argumentativos edificados pelos julgadores não foram construídos sob instrumentalização do gênero como categoria de análise das relações sociais. A mobilização do termo "gênero" surgiu somente em quatro acórdãos analisados, nos quais o mesmo desembargador relatou que uma das várias causas do tráfico sexual é a “discriminação de gênero".

Contudo, não houve preocupação em desenvolver o raciocínio jurídico em torno desse tipo de discriminação. Diante disso, a mobilização da argumentação sem a codificação das relações de gênero trouxe consigo o desmantelamento da tese de impessoalidade, neutralidade e universalidade que circundaria o universo do sentenciamento. $O$ apagamento da categoria de gênero em uma temática estritamente vinculada a dominações e a subversões sociais traz luz à ideologia jurisdicional dominante e o foro íntimo dos julgadores.

Destarte, nos acórdãos analisados, de modo geral, o conteúdo decisório e o material textual traduziram, sobremaneira, a reafirmação das estratificações de gênero, em poucos momentos rompendo com a dinâmica de controle localizada no seio social e no Sistema de Justiça Criminal. Numa perspectiva intertextual às reflexões elididas por Pierre Bourdieu, os resultados sugerem que a representação e construção simbólica do tráfico sexual, da prostituição e da vulnerabilidade mais se localizam no universo da dominação do que no da subversão do sistema jurídico. Por fim, não corresponderia a um equívoco afirmar que, assim como postulado por Carol Smart, o direito, na maioria dos acórdãos analisados, também se mostra orientado a um certo padrão de gênero: o masculino.

\section{CONCLUSÃO}

Neste trabalho, buscou-se refletir sobre as dinâmicas de (des)proteção do Sistema de Justiça Criminal sobre a mulher traficada que consentiu com seu tráfico para prostituição transnacional, 
num suposto cenário de vulnerabilidade social. A ação do Sistema Penal deve vir acompanhada de suportes epistemológicos críticos para compreender o entrelace entre agências de controle nos espaços de sociabilidade e nos campos institucionais, pois na seara de aplicação das normas jurídicas ocorrem processos de construções e de representações do tráfico sexual de mulheres, do consentimento e da vulnerabilidade.

Apesar dos esforços legislativos, como o advento da Lei 13.344/2016, juntamente com o Protocolo de Palermo, as categorias e os parâmetros para compreensão da questão do consentimento das mulheres no tráfico sexual têm sido levado ao crivo do Judiciário e, assim, objetos de estudos criminológicos e feministas. As pesquisas já realizadas no campo de investigação resultaram em conclusões sobre a relação entre tutela penal e tráfico sexual de mulheres: denunciam os empecilhos dos julgadores em garantir, nas práticas e nos discursos jurídicos, a primazia da igualdade de gênero prevista pela Carta Magna. Isso porque, considerando-se a realidade social e econômica da América Latina - e precisamente a brasileira-, as mudanças legislativas não são sinônimas de alteração de ruptura do patriarcado, e muito menos cumprem as promessas feitas pelo paradigma criminológico tradicional.

Com as análises engendradas pela Criminologia Crítica e Feminista, o discurso de proteção penal aos direitos humanos das mulheres traficadas vem sendo descortinado - e relativizado - pelo estudo da resposta jurisdicional aos casos judicializados. Na realidade, o estudo empírico realizado sobre os 12 acórdãos coletados (2012-2018) demonstrou o predomínio da reprodução e construção de pânicos morais e de estereótipos em torno da vulnerabilidade e do consentimento na dinâmica do tráfico sexual das mulheres. Em poucos momentos houve uma relativa ruptura desse paradigma jurídico que sedimentou um direito androcêntrico. Predominantemente, as simbologias e mecanismos de controle sobre o corpo da mulher ficaram evidentes não só pelo emprego do aporte da Análise do Discurso, mas também pela instrumentalização do recorte metodológico das Teorias Críticas do Direito.

A resposta jurisdicional dominante vem apontando que o tráfico sexual é inerentemente dominado pela vulnerabilidade social das mulheres traficadas, tratando-se de uma condição obrigatória para o fenômeno. Entretanto, essa visão jurisdicional vem sendo contestada pelas pesquisas empíricas no âmbito das análises socioantropológicas e do próprio Direito. Por conseguinte, a adoção das epistemologias feministas liberais possibilita a base crítica para a reflexão sobre a atuação do Sistema de Justiça Criminal. Afinal, ocorreria um equívoco metodológico abordar o tráfico sexual sob uma visão simplista, quando, na realidade, trata-se de um fenômeno multifacetado e moldado aos contextos de cultura e de sociabilidade em determinado tempo e local.

Não obstante, o estudo empírico empreitado revelou um apego da Justiça Criminal a sensos comuns e pânicos morais sobre o tráfico sexual, consentimento e vulnerabilidade. As narrativas 
argumentativas nos acórdãos evidenciaram que a aplicação da norma incriminadora mais se incumbe de fortalecer os estereótipos nas linguagens e nas ações do que romper com as dinâmicas de dissolução dos direitos humanos das mulheres traficadas.

Frente a isso, compreender o consentimento da mulher traficada como meio de afastar a norma incriminadora, como em raros momentos identificados pela análise dos acórdãos, traz consigo o reconhecimento da mulher como autodeterminada e emancipada, além de contribuir para a efetiva compreensão da pluralidade da indústria do sexo. Assim, descortinar os discursos e as práticas no Sistema de Justiça fomenta uma visão crítica sobre os invólucros morais e sobre as instituições que constroem e raramente desconstroem os padrões de gênero.

Conclui-se que, sendo o direito como uma forma de atividade humana construída pelo homem, é importante instrumentalizar estratégias de sensibilização do fenômeno jurídico com fundamento em uma visão dialética das relações sociais e da própria maneira de se compreender a ação do direito. Como consequência, ressignificar as concepções sobre construção social e jurídica dos gêneros significa centralizar as discussões sobre adequada tutela ao corpo da mulher traficada, retirando da órbita do Sistema de Justiça Criminal os debates criminológicos críticos e feministas tão imprescindíveis ao tema.

Destarte, a confiança na solução dos problemas do fenômeno jurídico por meio da ruptura da construção dos gêneros surge como proposta de solução para a alteração das imagens e sentidos padronizados nos acórdãos analisados - e possivelmente no trato às mulheres pelo Sistema de Justiça Criminal como um todo. Diante disso, trata-se de compreender na seara jurisdicional uma perspectiva bicéfala: que o tráfico sexual é fruto de complexas construções históricas e socioculturais das assimetrias nas relações de gênero; e que o paradigma criminológico tradicional elencado nos acórdãos, isto é, a mobilização do Direito Penal e do Estado como entes aptos e capazes a suprimirem o tráfico sexual, não surte os efeitos prometidos pela dogmática jurídicopenal de tutela penal dos direitos humanos.

\title{
BETWEEN CONSTRUCTIONS AND REPRESENTATIONS OF WOMEN'S TRAFFICKING FOR PROSTITUTION, VULNERABILITY AND CONSENT: A CRITICAL STUDY ABOUT THE APPLICATION OF THE INCRIMINATING LEGAL STANDARD BY THE CRIMINAL JUSTICE SYSTEM
}

\begin{abstract}
This study is based on research funded by FAPESP and CNPq. The main purpose of this study was to reflect about the jurisdictional response given to the application of the criminal law that criminalizes sexual trafficking, especially about judicial cases in which women consent to trafficking on a context of alleged vulnerability. This application involved deep discussions about consent as a means of dissolving the material typicity of this crime, since the concept of vulnerability is highly imprecise. After analyzing the criminal scene of repression of sex trafficking


and its intersection with the Criminal System, the parameter of vulnerability recognition was analyzed, with the support of the analytical categories of capitalism and gender. Finally, with the epistemological resources of Critical Criminology, Feminist Criminology and Discourse Analysis, the actions and discourses of the Criminal Justice System were questioned as aspects of constructions and representations of symbolism in the (deprotection of the sexual rights of women trafficked for sexual exploitation who consented to the phenomenon. The qualitative analysis of judgments published by the Federal Regional Courts has revealed that the jurisdictional response further strengthens the gender patterns of what breaks with the sexual control agencies over women.

Keywords: Criminal Justice System; trafficking in persons for sexual exploitation; prostitution; vulnerability; consent.

\section{REFERÊNCIAS BIBLIOGRÁFICAS}

AMOSSY, Ruth. Imagens de si no discurso: a construção do ethos. Tradução de Dilson Ferreira da Cruz et al. São Paulo: Contexto, 2005.

L'argumentation dans le discours. Paris: Armand Colin, 2006.

ANDRADE, Vera Regina Pereira de. Criminologia e feminismo: da mulher como vítima à mulher como sujeito de construção da cidadania. In: CAMPOS, Carmen Hein de. Criminologia e feminismo. Porto Alegre, Sulina, 1999.

Pelas mãos da criminologia: o controle penal para além da (des)ilusão. Coleção pensamento criminológico (n. 19). Rio de Janeiro: ICC/Revan, 2012.

Violência sexual e sistema penal: proteção ou duplicação da vitimação feminina. In: Sequência: Estudos jurídicos e políticos, Florianópolis, v. 33, n. 17, p. 87-113, jul. 1996

BARATTA, Alessandro. O paradigma do gênero: da questão criminal à questão humana. In: CAMPOS, Carmen Hein de. (Org.). Criminologia e feminismo. Porto Alegre: Sulina, 1999 b.

BARRY, Kathleen. The prostitution of sexuality. New York: New York University Press, 1995.

BORGES, Paulo César Corrêa. A tutela penal dos direitos humanos. Revista Espaço Acadêmico, Maringá, v. 12, n. 134, 2012. P. 84. Disponível em: < http://www.periodicos.uem.br/ojs/index.php/EspacoAcademico/article/view/15059/9457>. Acesso em 10 out. 2019.

Tráfico de pessoas: exploração sexual versus trabalho sexual escravo. In: BORGES, Paulo César Corrêa. (Org.). Tráfico de pessoas para exploração sexual: prostituição e trabalho sexual escravo. São Paulo: NETPDH : Cultura Acadêmica, 2013.

BOURDIEU, Pierre. O poder simbólico. Rio de Janeiro: Bertrand Brasil, 1989.

BRAGA, Ana Gabriela M. A vítima-vilã: a construção da prostituta e seus reflexos na políticacriminal. In: BORGES, Paulo César C. (Org.). Tráfico de pessoas para exploração sexual: Prostituição e trabalho sexual escravo. São Paulo, 2013

BRASIL. Decreto $\mathrm{n}^{\circ}$ 5.017, de 12 de março de 2004. Promulga o Protocolo Adicional à Convenção das Nações Unidas contra o Crime Organizado Transnacional Relativo à Prevenção, Repressão e Punição do Tráfico de Pessoas, em Especial Mulheres e Crianças, Brasília, DF, mar. de 2004.

Lei 11.106, de 28 de Março de 2005. Altera os arts. 148, 215, 216, 226, 227, 231 e acrescenta o art. 231-A ao Decreto-Lei no 2.848, de 7 de dezembro de 1940 - Código Penal e dá outras providências, Brasília, DF, mar. de 2005.

. Lei 12.015, de 07 de Agosto de 2009. Altera o Título VI da Parte Especial do DecretoLei no 2.848, de 7 de dezembro de 1940 - Código Penal, e o art. 1oda Lei no 8.072, de 25 de 
julho de 1990, que dispõe sobre os crimes hediondos, nos termos do inciso XLIII do art. 5o da Constituição Federal e revoga a Lei no 2.252 , de 1 o de julho de 1954, que trata de corrupção de menores, Brasília, DF, ago. 2009.

Lei 13.344 de 6 de Outubro de 2016. Dispõe sobre prevenção e repressão ao tráfico interno e internacional de pessoas e sobre medidas de atenção às vítimas, Brasília, $\mathrm{DF}$, out. de 2016.

Tribunal Regional Federal da $1^{a}$ Região. Acórdão de decisão que deu parcial provimento de pedido de absolvição por tráfico sexual, em razão da absolvição pela prescrição do crime de falsidade ideológica e condenação por tráfico de pessoas para exploração sexual. Apelação Criminal no 2001.35.00.004344-8/GO. Ministério Público Federal e Roberto Zacarias de Morais. Relator: Desembargador Cândido Ribeiro. 11 de março de 2014.

Tribunal Regional Federal da $1^{a}$ Região. Acórdão de decisão que deu provimento de pedido de absolvição por tráfico sexual, por não existir prova suficiente para a condenação. Apelação Criminal no 2005.38.03.004911-6/MG. Ministério Público Federal e Auta Maria de Faria Aureliano. Relator: Tourinho Neto. 3 de dezembro de 2012c.

Tribunal Regional Federal da $1^{a}$ Região. Acórdão de decisão que negou provimento de pedido de absolvição por tráfico sexual, em razão da materialidade e autoria comprovadas. Apelação Criminal no 2007.36.00.015308-2/MT. Ministério Público Federal e Fernando de Oliveira Rodrigues. Relator: Desembargador Tourinho Neto. 20 de novembro de 2012.

Tribunal Regional Federal da $1^{\mathrm{a}}$ Região. Acórdão de decisão que negou provimento de pedido de absolvição por tráfico sexual, em razão do consentimento não excluir a culpabilidade. Apelação Criminal n ${ }^{\circ}$ 0001188-98.2011.4.01.3000/AC. Ministério Público Federal e Edson Santos. Relator: Desembargador Tourinho Neto. 23 de março de 2013 b.

Tribunal Regional Federal da $3^{\text {a }}$ Região. Acórdão de decisão que julgou prejudicada a ação, em razão da ocorrência de abolitio criminis. Apelação Criminal $\mathrm{n}^{\mathbf{0}}$ 000378495.2010.4.03.6181/SP. Ministério Público Federal e Lilian Helena Chaves da Cunha. Relator: Desembargador Wilson Zauhy, Tourinho Neto. 20 de setembro de $2017 \mathrm{~b}$.

Tribunal Regional Federal da $5^{\text {a }}$ Região. Acórdão de decisão que deu provimento de pedido de condenação por tráfico sexual, em razão da tipicidade da conduta. Apelação Criminal $n^{0}$ 8336/RN. Ministério Público Federal, Mariano Loreti, Fernandino Brito Araújo. Relator: Desembargadora Cíntia Menezes Brunetta. 17 de dezembro de 2013a.

Tribunal Regional Federal da $5^{\text {a }}$ Região. Acórdão de decisão que negou provimento de pedido de condenação por tráfico sexual, em razão da atipicidade da conduta. Apelação Criminal n ${ }^{\circ}$ 15004/RN. Ministério Público Federal, Paulo Jorge da Silva Oliveira e Manuel Oliveira da Silva. Relator: Desembargador Carlos Wagner Dias Ferreira. 12 de dezembro de 2017a.

CASTILHO, Ela Wiecko Volkmer de. A criminalização do tráfico de mulheres: proteção das mulheres ou reforço da violência de gênero? In: Cad. Pagu, Campinas, n. 31, p. 101-123, dez. 2008. Disponível em: http://www.scielo.br/pdf/cpa/n31/n31a06. Acesso em: 20 set. 2018.

Problematizando o conceito de vulnerabilidade para o tráfico internacional de pessoas. In: Tráfico de Pessoas: uma abordagem para os direitos humanos. Brasília: Ministério da Justiça, 2013. Disponível em: < http://www.justica.gov.br/sua-protecao/trafico-depessoas/publicacoes/anexos/cartilha traficodepessoas uma abordadem direitos_humanos.pdf $>$. Acesso em: 10 nov. 2018.

COBO, Rosa. Hacia una nueva política sexual. Las mujeres ante la reacción patriarcal. Catarata: Madrid, 2011.

COSTA, Alexandre A.; COELHO, Inocêncio M. Teoria Dialética do Direito: a filosofia jurídica de Roberto Lyra Filho. Brasília: Faculdade de Direito da Universidade de Brasília, 2017

DOEZEMA, Jo. Loose women or lost women? The re-emergence of the myth of white slavery in contemporary discourses of trafficking in women. Gender issues, v. 18, n. 1, p. 23-50, 1999. 
Disponível em: <https://link.springer.com/article/10.1007/s12147-999-0021-9>. Acesso em: 10 out. 2018.

DWORKIN, Andrea. Pornography: men possessing women. Nova Iorque: Plum, 1989.

FAIRCLOUGH, Norman. Analysing discourse. New York: Routledge, 2003.

FAIRCLOUGH, Norman; DE MELO, Iran Ferreira. Análise crítica do discurso como método em pesquisa social científica. Linha d'Água, v. 25, n. 2, p. 307-329, 2012. Disponível em: < http://www.journals.usp.br/linhadagua/article/download/47728/51460>. Acesso em 04 nov. 2018.

FLORES, Joaquín Herrera. De habitaciones propias y otros espacios negados: una teoría de las opresiones patriarcales. Universidad de Deusto Instituto de Derechos Humanos: Bilbao, 2005.

GRECO, Alessandra Orcesi Pedro; RASSI, João Daniel. Crimes contra a dignidade sexual. São Paulo: Atlas, 2010.

GOLDMAN, Emma. Trafico de mujeres y otros ensayos sobre feminismo. Barcelona: Anagrama, 1977.

IGREJA, Rebecca Lemos. O Direito como objeto de estudo empírico: o uso de métodos qualitativos no âmbito da pesquisa empírica em Direito. In: MACHADO, Maíra Rocha (Org.). Pesquisar empiricamente o direito. São Paulo: Rede de Estudos Empíricos em Direito, 2017.

JULIANO, Dolores. El trabajo sexual en la mira: polémicas y estereotipos. In: PISCITELLI, Adriana (Org.). Cadernos Pagu: Mercado do sexo. n. 25 Campinas: UNICAMP, 2005.

KEMPADOO, Kamala. Mudando o debate sobre o tráfico de mulheres. Cadernos Pagu, Campinas, SP, n. 25, p. 55-78, dez. 2005. Disponível em: < http://www.scielo.br/pdf/\%0D/cpa/n25/26522.pdf>. Acesso em 05 nov. 2018.

LAURETIS, Teresa de. A tecnologia do gênero. In: HOLLANDA, Heloisa Buarque de. Tendências e impasses: o feminismo como crítica da cultura. Rio de Janeiro: Rocco, 1994.

LAURETIS, Teresa de. A tecnologia do gênero. Tendências e impasses: o feminismo como crítica da cultura. Rio de Janeiro: Rocco, v. 132, p. 123-132, 1994.

LOMBroso, Cesare; FERRERO, Guglielmo. Criminal Woman, the Prostitute, and the Normal Woman. Translated by Nicole Hahn Rafter and Mary Gibson. Durham: Duke University Press, 2004.

LOWENKRON, Laura. Consentimento e vulnerabilidade: alguns cruzamentos entre o abuso sexual infantil e o tráfico de pessoas para fim de exploração sexual. Cadernos Pagu, Campinas, SP, n. 45, p. 225-258, abr. 2015. Disponível em: < https://periodicos.sbu.unicamp.br/ojs/index.php/cadpagu/article/view/8645215/0>. Acesso em: 14 nov. 2018.

MACKINNON, Catharine A. Hacia una teoría feminista del Estado. Madrid: Cátedra, 1995.

MCCKLINTOCK, Anne. Sex Work and Sex Workers: introduction. Social Text, n. 37. Winter, 1993, p. 1-10. Acesso em: <https://www.jstor.org/stable/466255>. Acesso em: 10 out. 2018.

MELKEVIK, Bjarne. Vulnerabilidade, direito e autonomia: um ensaio sobre o sujeito de direito. Revista da Faculdade de Direito da UFMG, n.71, p. 639-674, 2018. Disponível em: $<$ https://www.direito.ufmg.br/revista/index.php/revista/article/view/1877>. Acesso em 29 nov. 2018.

MÉDICI, Sérgio de Oliveira. A condição feminina na reforma penal projetada de 1999. In REALE JÚNIOR, Miguel; PASCHOAL, Janaína (Coord.). Mulher e direito penal. Rio de Janeiro: Forense, 2007.

OLIVEIRA, Ana Sofia Schmidt de. A vítima e o direito penal. São Paulo, RT, 1999. 
PIMENTEL, Sílvia. A superação da cegueira de gênero: mais do que um desafio-um imperativo. Revista Direitos Humanos, v. 2, p. 27-30, 2009. Disponível em: $<$ http://www.dhnet.org.br/dados/revistas/a pdf/revista sedh dh 02.pdf $>$. Acesso em 14 nov. 2018.

PISCITELLI, Adriana. Corporalidade em Confronto: Brasileiras na indústria do sexo na Espanha. Revista Brasileira de Ciências Sociais, vol. 22, $\mathrm{n}^{\mathrm{o}}$ 64, p. 17-32, 2007. Disponível em: $<$ http://www.scielo.br/pdf/rbcsoc/v22n64/a02v2264.pdf>. Acesso em 26 out. 2018.

. Sujeição ou subversão? migrantes brasileiras na indústria do sexo na Espanha. Revista História e Perspectivas, $n^{\circ}$ 35, Universidade Federal de Uberlândia, Agosto-Dezembro de 2006. Disponível em:

http://www.seer.ufu.br/index.php/historiaperspectivas/article/view/19060/10247>. Acesso em: 10 nov. 2018.

PÊCHEUX, Michel; ORLANDI, Eni Puccinelli. Semântica e discurso: uma crítica à afirmação do óbvio. Editora da UNICAMP, 1995

REGINATO, Andréa Depieri de A. Uma introdução à pesquisa documental. In: MACHADO, Maíra Rocha (Org.). Pesquisar empiricamente o direito. São Paulo: Rede de Estudos Empíricos em Direito, 2017.

ROXIN, Claus. Derecho Penal - Parte General. Fundamentos. La Estructura de la Teoria del Delito. Madri: Civitas, 1997.

RUBIO, David Sánchez. Reflexiones en torno al concepto contemporáneo de trabajo esclavo y la prostitución. In: BORGES, Paulo César Corrêa Borges (Org.). Tráfico de pessoas para exploração sexual: prostituição e trabalho sexual escravo. NETPDH; Cultura Académica Editora: São Paulo, 2013.

. A imigração e o tráfico de pessoas face a face com a adversidade e os direitos humanos: Xenofobia, Discriminação, Exploração Sexual, Trabalho Escravo e Precarização do Trabalho. Revista da Faculdade de Direito da UFG, [S.1.], v. 39, n. 1, p. 13- 51, fev. 2015. Disponível em:

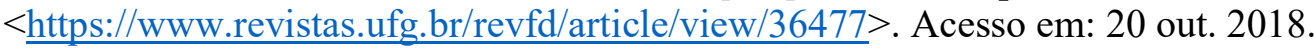

RUBIN, Gayle. O Tráfico de Mulheres: notas sobre a "economia política" do sexo. Tradução de Christine Rufino Dabat, Edileusa Oliveira da Rocha, Sonia Corrêa. Recife: SOS Corpo, 1993

SAFFIOTI, Heleieth Iara Bongiovani. O poder do macho. São Paulo: Moderna, 1987.

SANTOS, Boaventura de Sousa. Crítica da razão indolente: contra o desperdício da experiência. Porto: Edições Afrontamento, 2000.

SANTOS, Boaventura de Sousa; GOMES, Conceição; DUARTE, Madalena. Tráfico sexual de mulheres: representações sobre ilegalidade e vitimação. Revista Crítica de Ciências Sociais, $n$.

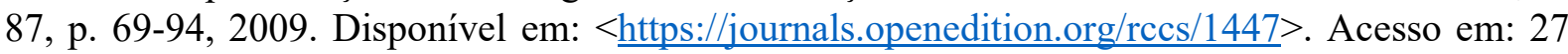
out. 2018.

SCHRITZMEYER, Ana Lúcia Pastore. Sortilégio de saberes: curandeiros e juízes nos tribunais brasileiros (1900-1990). São Paulo: IBCCRIM, 2004.

SCOTT, Joan Wallach. Gênero: uma categoria útil de análise histórica. Educação \& Realidade. Porto Alegre, v. 20, p.71-99, n. 2, jul./dez. 1995. Disponível em: $<$ https://seer.ufrgs.br/educacaoerealidade/article/view/71721/40667>. Acesso em: 10 nov. 2018.

SMART, Carol. La mujer del discuro jurídico. In: LAURRARI, Elena. Mujeres, Derecho penal y criminologia. Madrid: Silgo Veintiuno, 1994.

. La teoría feminista y el discurso jurídico. In: BIRGIN, Haydée. EI Derecho en el Género

y el género en el derecho. Buenos Aires: Editorial Biblos, 2000. 

Paul, 1976.

. Woman, crime and criminology: a feminist critique. London: Routledge and Kegan

SILVA, Paulo Eduardo Alves da. Pesquisas em processos judiciais. In: MACHADO, Maíra Rocha (Org.). Pesquisar empiricamente o direito. São Paulo: Rede de Estudos Empíricos em Direito, 2017.

SMAUS, Gerlinda. Das Strafrecht und die gesellschaftliche differenzierung. Baden-Baden: Nomos, 1998.

VENSON, Anamaria Marcon. Tráfico internacional de pessoas para exploração sexual? Uma análise de processos-crime (1995-2012). Rev. Estud. Fem., Florianópolis, v. 25, n. 2, p. 571-591, Aug. 2017. Disponível em: <https://www.jstor.org/stable/90007977>. Acesso em 04 nov. 2018.

WARAT, Luís Alberto; ROCHA, Leonel Severo. O direito e sua linguagem: 2a. versão. SA Fabris, 1995.

Trabalho enviado em 20 de dezembro de 2018

Aceito em 13 de março de 2019 